\title{
UN TEMA FECUNDO: LAS "ENCONTRADAS CORRESPONDENCIAS”*
}

La forma epigrama, tal como la conocemos, nació en la segunda mitad del siglo II a.C., durante los años "alejandrinos" de la literatura griega. No es que antes no haya habido epigramas; pero éstos -en particular los de Simónides (siglo vI/v a.C.) - eran, de acuerdo con la etimología, textos hechos para ser grabados sobre ( $\dot{\pi} \pi$ í) piedra, mármol, bronce, mientras que los epigramatistas alejandrinos los escribieron con pluma y tinta, para que fueran lectura de todos, y no sólo de quienes acertaban a pasar frente a una estela o una estatua conmemorativa. Y en lugar de referirse a un personaje famoso o a un hecho histórico, los poetas tenían como tema cuanto se les antojara. Pero esta libertad, aunque enorme, no era absoluta: los nuevos epigramatistas debían ceñirse a la norma de la brevedad; y, naturalmente, lo que hicieron fue sacar partido de esta traba, diciendo mucho en pequeño espacio y extremando el arte de la concisión ingeniosa o de la alusión erudita. Muchísimos epigramas, desde

*El presente artículo es reelaboración de la "Nota (prescindible) a unos sonetos de sor Juana", decano de mis estudios sorjuaninos, publicado en El Rehilete, núm. 11 (mayo de 1964), pp. 45-56. La intención sigue siendo la misma: poner los tres sonetos de "encontradas correspondencias" de sor Juana en su contexto histórico-literario. En la presente versión hay gran número de materiales, así como notas de pie de página, que omití en 1964 porque El Rehilete no era una revista "profesional". Naturalmente, en los casi cuarenta años transcurridos he reunido muchos datos que antes no conocía, por ejemplo los que ofrece José LARA GARRIDO, "Amado y aborrecido: trayectoria de un dubbio poético”, AnMal, 3 (1980), núm. 1, pp. 113-148, y addendum en la misma revista, 7 (1984), núm.1, pp. 139-140. 
la era clásica hasta la bizantina, constan de un solo dístico: un hexámetro y un pentámetro.

El primero que hizo epigramas libres, sueltos de toda obligación cívica, parece haber sido Leónidas de Tarento (primera mitad del siglo III a.C.), uno de los astros de la era alejandrina. Y su ejemplo fue seguido, durante muchos siglos, por los poetas de la era post-alejandrina y la bizantina. Muy pronto comenzó a circular un florilegio de epigramas ${ }^{1}$, la Guirlanda de Meleagro (hacia 80 a.C.), a la cual siguieron la Corona de Filipo (mediados del siglo I d.C.), el Anthologion de Diogeniano (siglo II), el Círculo de Agatías (siglo vi) y la magna recopilación de Céfalas (hacia 900 d.C.). Cada antología aprovechaba a manos llenas la cosecha de la antecedente. Culminación de estas recopilaciones es la célebre Anthologia Palatina, compilada hacia el año 980, que contiene 3700 epigramas, resultado de casi mil quinientos años de vigencia del género. (El ya antiquísimo Leónidas de Tarento sigue siendo admirado: en la Palatina hay un centenar de epigramas suyos.)

El compilador de la Anthologia Palatina pone antes de cada epigrama el nombre del autor, pero a veces el epigrama le ha

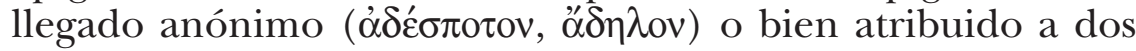
poetas distintos. Es lo que sucede con el primer epigrama que mencionaré; no sabe el compilador si es de Polemón rey del Ponto (fines del siglo I) o de Lucilio (medio siglo posterior). Quien habla en él es un amante que sufre la intolerable tortura

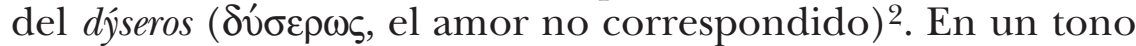
que tiene algo de súplica y algo de reclamación o recriminación al dios Eros - ese Eros de cuyas travesuras y malas mañas se han quejado poco antes Mosco, Meleagro y el pseudo-Teócrito del Idilio $X^{3} X^{3}-$, el desdichado amante le dice: "O elimina por completo el $\varphi \imath \lambda \varepsilon \tilde{i v}$ (el amar), o añádele el $\varphi \imath \lambda \varepsilon \tilde{\sigma} \sigma \theta \alpha \imath$ (el ser ama-

${ }^{1}$ Lo equivalente, hoy, sería una antología de sonetos. El soneto -dice Fernando de Herrera en sus Anotaciones (1580), a propósito del primero de Garcilaso- "sirve en lugar de los epigramas i odas Griegas y Latinas", ya que es "capaz de todo argumento".

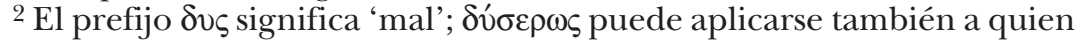
no sabe amar, o a quien ama a un sujeto indigno (amor mal empleado,

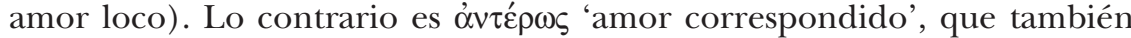
puede ser el eros que le disputa la victoria a otro eros (y Anteros es a veces el dios vengador del Eros desdeñado). Sobre Eros y Anteros puede verse A. AlATORRE, "Andanzas de Venus y Cupido", Estudios de folklore y literatura dedicados a Mercedes Díaz Roig, El Colegio de México, 1992, pp. 366-368.

${ }^{3}$ Cf. A. Alatorre, art. cit., sobre todo pp. 339-347. 
do)". El conceder la correspondencia amorosa será tan buen remedio como la indiferencia total (Anthologia Palatina, libro V, epigrama 68):

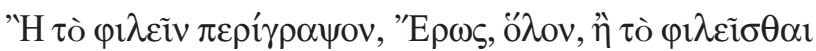

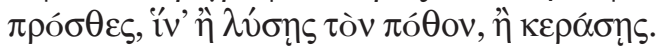

Tres o cuatro siglos después (en la segunda mitad del Iv), Rufino hizo dos reelaboraciones, también en dísticos. En un epigrama (Anth. Pal., V, 97) introduce la metáfora de las saetas de Eros: "Si nos flechas a ambos por igual, eres un dios; si disparas sólo por un lado, no lo eres"; en el otro $(\mathrm{V}, 88)$ se vale de la metáfora del fuego, y no llama a Eros por su nombre, sino por

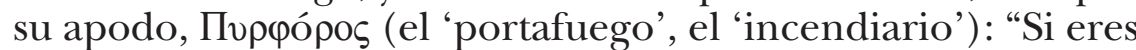
incapaz de inflamar dos corazones a la vez, mejor no inflames ninguno".

Los poetas latinos de tiempos de Rufino seguían bebiendo en fuentes griegas. Prueba elocuente de ello es que su contemporáneo Ausonio, profesor de gramática en Burdeos -y grammatica significaba lectura y estudio de autores latinos y griegos-, haya hecho no una, sino dos versiones del epigrama que acabo de comentar. La primera dice así:

Hoc quod amare vocant, solve aut misceto, Cupido: aut neutrum flammis ure, vel ure duos.

La segunda dice lo mismo, aunque no se dirige a Cupido sino a Dione, que era una de las denominaciones de Venus:

\section{Aut restinguere ignem, quo torreor, alma Dione, aut transire iube, vel fac utrimque parem ${ }^{4}$.}

No contento con esto, Ausonio desarrolló de varias maneras el tema del dýseros. Así en el epigrama LVI (Hanc volo quae non vult...), que consta de cuatro dísticos:

Quiero a ésta, que a mí no me quiere; y a aquélla, que me quiere, yo no la quiero. Venus pretende dominar mi corazón, pero no satisfacerlo. Desprecio las caricias que se me brindan y me quedo sin las que se me niegan. No quiero hartar mi pecho, pero tam-

${ }^{4}$ Estos epigramas llevan los números XC y XCI en la edición de H.G.E. White (Loeb Classical Library). 
poco torturarlo. No apetezco una Diana ceñida con doble cinturón, ni una Venus desnuda. Lo que busco es una mujer discreta que me ofrezca amores bien medidos, acompañados de eso que se llama "quiero" y "no quiero".

No hay aquí "incendio" ni otra metáfora alguna; sólo razonamiento y reiteración discursiva de las antítesis. Pero, evidentemente, Ausonio vio que las antítesis se prestaban para el diálogo, y entonces escribió (epigrama xxII, Hanc amo quae me odit...):

-Amo a ésta, que me odia, y en cambio odio a aquélla, que me ama. Resuelve, si puedes, oh alma Venus, este conflicto.

- No me costará ningún trabajo: haré que la primera te ame y la segunda te odie.

-Así seguirá siendo igual mi tortura.

$-¿$ Quieres entonces amar a las dos?

- Sí, si las dos se enamoran de mí.

-Eso, Marco, es asunto tuyo: si quieres ser amado, ama.

Este epigrama va seguido de otro (xxiII, Suasisti, Venus...), que expone un caso diferente:

- Me has persuadido, oh Venus, a amar a dos muchachas difíciles $^{5}$ : las dos me aborrecen. Tendrás que darme, pues, un nuevo consejo.

-Conquista a las dos con regalos.

-Bien lo quisiera, pero mis negocios andan mal.

-Gánatelas con promesas.

- Al pobre no le creen palabra.

-Pon por testigos a los dioses.

-Estaría muy mal engañar a los dioses.

-Ronda sus casas de noche.

-Temo que de noche me asalten.

-Escríbeles versos de amor.

-Imposible: no tengo trato con Apolo y las Musas.

-Derriba sus puertas.

- Temo el castigo de la ley.

-Pues eres un tonto: te estás muriendo de amor, y no quieres morir por amor.

-Prefiero que me llamen desdichado, y no desdichado y reo de un delito.

5 "Amare duas dyseros", dice el texto latino. 
-Te he aconsejado lo mejor que he podido. Acude a otros consejeros.

-¿A quiénes?

-A Fedra, a Elisa, a Cánace, a Filis y a la desdeñada por Faón; que ellas te cuenten qué determinación tomaron.

- ¿Ese consejo me das?

-Sí. Es el que se da a los desdichados.

O sea: 'Para los rematadamente infelices en amor no hay más receta que el suicidio'. En efecto, Fedra, Elisa (Dido), Cánace, Filis y la desdeñada por Faón (Safo) se dieron muerte a causa de su desdicha. (Por supuesto, la traviesa diosa habla con ironía; lo que se sobreentiende es: 'Tú no das señas de estar enamorado de veras. Quédate como estás'.)

\section{II}

Ausonio fue uno de los poetas clásicos que alimentaron la poesía latina de la Edad Media, sobre todo a partir del "renacimiento" del siglo XII. Era el maestro de la agudeza, de las antítesis, del juego verbal y conceptual. En ese mismo siglo XII nace en Provenza la poesía lírica romance, y una de sus formas características es la tensó: debate, planteamiento de dilemas, duda o pregunta ingeniosa a la cual debe contestarse de manera aún más ingeniosa. Los distintos temas y técnicas de la tensó "circularon desde Provenza, a través de Francia y la lírica galaico-portuguesa, hasta los cancioneros castellanos. Es un largo proceso que se cierra en 1511, cuando todavía el Cancionero general de Hernando del Castillo dedica una sección a las preguntas". Ya en la lírica trovadoresca "amor y odio entrecruzan sus líneas en la búsqueda de la correspondencia, ideal latente mediatizado por el juego, el contrabalanceo entre la amada desdeñosa y la amante aborrecible" 6 , de lo cual es buen ejemplo esta "Pregunta de Joan de Mena":

Decidme vos, amadores, si es pesar o placer el diligente deseo; y de todas las colores

${ }^{6}$ LARA GARRIDO, art. cit., p. 115. En adelante, LARA-I significará el artículo principal, y LARA-II el addendum. 
cuál tiene ( sin negro ser) mayor deudo con lo feo;

y si puede la victoria seguir al hombre vencido en algún trance jamás;

o quién ha más dulce gloria: el querido en ser querido o el que quiere en querer más 7 .

Por tres gradas de tres versos cada una llega Mena a la cuarta, donde da a entender lo que él opina: la fine pointe del amor cortés está en sentir el desdén de la dama no como una desdicha, sino como una gloria superior quizá a la gloria del amante correspondido, pues impulsa al desfavorecido a extremar y acendrar su amor.

En una composición más larga ("Cuydar me haze cuydado...”) intercala el mismo Juan de Mena estas dos coplas:

Por que más mi mal avise

los que saben o supieren:

a do me quieren no quise

y quiero do no me quieren.

Más con muerte, siendo amado, soy entero,

que con vida deseado

de mal quiero.

Grande fue el atrevimiento

que cobré con el deseo,

y mayor el pensamiento

de cuitas en que me veo;

cuanto fui más atrevido por amores,

tanto soy más afligido

de dolores ${ }^{8}$.

El tópico cancioneril sigue vivo a comienzos del siglo XVI. Así, Rodrigo Dávalos pregunta “cuál será mayor cuidado",

7 Cancionero castellano del siglo XV, ed. R. Foulché-Delbosc (NBAE, t. 19), pp. 199-200.

8 Cancionero citado, p. 194. 
aquello que más amáis que no lo podáis haber y ser querido, o que por vos lo tengáis no siendo contento, y ser aborrecido,

y Luis de Salazar le responde por los mismos consonantes:

Aquel mayor mal, si miráis, destos dos que (a mi creer) vos ha herido, es aquello a quien tratáis no vos quiere bien, ni ver sino perdido ${ }^{9}$.

Así, pues, Salazar no ve de ninguna manera que el amar a una dama desdeñosa pueda llamarse "gloria".

Muy poco después, Juan Boscán expone el dilema cancioneril en metro italiano. Se dirige a la dama y, después de reprocharle sus constantes desdenes, le dice:

Con desamor quizá fuera amansado el desamor de vuestro sentimiento, y así quedara yo menos dañado;

mas es mejor amaros desamado, y en esto vivir yo de mí contento, que, sin amaros, ser de vos amado ${ }^{10}$.

O sea que Boscán se siente "contento" de sí mismo al seguir amando pese a los desdenes.

Pero ya el curioso poeta judío Antón de Montoro, "ropero" (sastre) de Córdoba, poco posterior a Mena, había dado un novedoso giro a la cuestión. Le recuerda Montoro a cierto amigo el antiguo "argumento" o "silogismo" poético de la amada desdeñosa y la amante desdeñada, y le dice:

${ }^{9}$ Cancionero general recopilado por Hernando del Castillo, Valencia, 1511, ff. cliv-clv; LARA-I, p. 116.

10 Boscán, soneto "Si sospiros bastasen a moveros...", Obras poéticas, ed. M. de Riquer, A. Comas y J. Molas, Barcelona, 1957, p. 190. 
Pues tened, señor y amigo, que muchos lo contendían, pero no lo distinguían (ciertamente vos lo digo).

Él va a "distinguir": no va a especular en abstracto, sino a presentar un caso específico y concreto, a saber:

Un escudero andaba

por el grande oceano

$y$, pasado el verano, contra norte navegaba.

El susodicho levaba en su guarda dos doncellas.

Él yendo así con ellas, tormenta los afincaba..;

pero antes de proseguir con la tormenta, Montoro explica que el escudero era amado por una de las doncellas con amor "muy más firme que columna", mientras que a quien él amaba "más que cosa alguna" era a la otra. Pues bien, la tempestad es horrorosa: vientos, chubasco, olas, vela rota, mástil quebrado...; poco más, y será el naufragio y la muerte de los tres navegantes. Pero he aquí que

en esta presecución y tormenta peligrosa, una voz muy pavorosa oyeron a la sazón (como en revelación), que diz: Conviene lanzar una déstas a la mar si quieres consolación.

Los tres oyen esa voz sobrenatural, que domina el fragor de la tormenta, pero es el escudero quien debe decidir cuál de las dos doncellas debe ser lanzada al mar. Y ahora viene la pregunta:

Señor, pues vos he contado toda la mi intención, de vuestra gran discreción sea esto declarado: este tal enamorado, según razón y derecho, 
¿cuál debe lanzar de fecho para cumplir lo mandado?

La respuesta, escrita no sólo en el mismo número de coplas, sino también con las mismas rimas, recalca lo terrible del trance ("cuando el pavor lo espantaba / con sus esquivas centellas") e insiste en el conflicto erótico, para concluir, sin más razonamiento:

Entendida la questión, sin hacer más luenga prosa, a la doncella fermosa que él amaba en perfección, aquélla debe guardar, y la otra condenar a cualquier tribulación.

Así, pues, la condenada a morir es la doncella que ama al escudero y a quien él no ama. Las coplas, sin embargo, no terminan con esto, sino con un cabo sorprendente:

Mas cuanto al seso dado, non vale la conclusión; que Dios ama con razón a aquel de quien es amado; y a quien le tiene olvidado, con entendimiento estrecho, non le quita su despecho nin le perdona el pecado.

O sea: la solución que se ha dado al problema vale sólo en la esfera humana. Es justo que el escudero salve a su amada y eche al mar a la desamada; pero Dios, que nos ama a todos, quiere la correspondencia de todos, y condena a tribulación eterna a cuantos no lo aman ${ }^{11}$.

Unos decenios después, Francisco Naharro, desde León, le hace a Juan de Molina, que vive en Salamanca, la siguiente pregunta:

11 Cancionero de Antón de Montoro, ed. F. Cantera Burgos y C. Carrete Parrondo, Madrid, 1984, núms. 41 y 42 (he hecho un par de enmiendas métricas); LARA-I, pp. 116-121. 
E mi questión será que una dama que sirve un galán de quien ha manzilla; si mucho la sirve, más lo desama; la que él ver no quiere lo precia y lo ama: ¿a cuál os parece que debo seguilla?

El galán, pues, quiere a una dama de quien no recibe sino manzilla ('dolor', 'heridas'); cuanto más amor le muestra, tanto más lo aborrece ella; la otra dama está enamorada de él, pero él no quiere ni verla. '[Ese galán soy yo]: ¿con cuál de ellas debo quedarme?'. He aquí la respuesta (con idénticas palabras-rimas) de Juan de Molina:

Respondo, a mi ver, que pues esa dama de sus servidores no tiene manzilla y a quien la quiere tanto desama, debéis de dejalla y seguir la que os ama, aunque se os haga penoso seguilla12.

Si bien no hay aquí mención del barco, ni de la tempestad, ni de la voz poderosa que ordena arrojar a una de las mujeres al mar, la situación es la misma. Y la respuesta es contraria a la de Montoro: el galán debe quedarse con aquella que lo ama, aunque él no la ame (el verso final concede, cuerdamente, que la vida futura de la pareja podrá ser no muy placentera).

A mediados del siglo xvI, Gregorio Silvestre pregunta:

Servís con grande querer una muy hermosa dama, mas ella no os puede ver; y otra igual que aquésta os ama todo cuanto puede ser. Ofréceos navegar; viene el navío a quebrar; metéisos en un batel; no podéis ir tres en él: ¿cuál echaréis a la mar?

Hay en esta pregunta un detalle realista: el navío se quiebra (por qué causa, no importa) y hay que echar mano de un batel,

12 Cancionero de Juan de Molina (Salamanca, 1527), ed. Eugenio Asensio, Valencia, 1952, pp. 76-78; LARA-I, pp. 119-120. (No tener manzilla es aquí no tener 'dolor' o ‘compasión' del galán: conducta de la belle dame sans merci.) 
de una lancha salvavidas en que no caben sino dos personas. Pero falta la importantísima voz sobrenatural, que Silvestre parece dar por sobreentendida. La pregunta va dirigida a Luis Barahona de Soto, el cual responde evasivamente:

\author{
Que cumpla mi obligación \\ manda la razón primero; \\ y voluntad, con pasión, \\ que socorra a la que quiero, \\ sin tener cuenta en razón. \\ No se conciertan jamás; \\ mas, pues una ha de ir atrás, \\ mi sentencia diréis vos \\ si decís cuál de las dos \\ puede en los amantes más ${ }^{13}$.
}

O sea: para cumplir mi obligación, la razón me dice una cosa y la voluntad otra del todo contraria. Obviamente, lo razonable es pagar la deuda de agradecimiento a la dama que, sin ser amada, ama al galán "todo cuanto puede ser"; lo malo es que la pasión amorosa ignora razones. ¿Cómo cumplir entonces la obligación? Barahona le devuelve la pelota a Silvestre: si éste, con su experiencia, le explica quién cala más hondo, la que nos hace sentir la gloria de amar, o la que nos muestra la gloria de ser amado, él, Barahona, adoptará su "sentencia".

Silvestre, por lo visto, tomó en serio el reto y, agarrando el toro por los cuernos, dedicó al asunto una composición lar$\mathrm{ga}^{14}$. Por principio de cuentas, retoca un poco la pregunta:

Amáis una linda dama y ella a vos no os puede ver; otra tan hermosa os ama todo lo que puede ser. Sucédeos navegar... [etc.]

13 Gregorio Silvestre, Obras, Lisboa, 1592 [edición póstuma], ff. 61-62; LARA-I, pp. 123-124.

${ }^{14}$ La cosa no es del todo segura. Es una composición que se encuentra, anónima, en el manustrito 3806 de la B.N.M., fechado en 1575 (seis años después de la muerte de Silvestre); pero Lara Garrido, que la publica por primera vez (LARA-I, pp. 125-127), da buenas razones para concluir que es obra de Silvestre. 
La respuesta es una glosa en gran forma: los nueve versos de la pregunta sirven de remate a otras tantas coplas reales. He aquí la primera:

En los casos de afición, do el amor su fuerza emplea, no hay justicia ni razón, ni ninguna ley que sea en favor de obligación; que el amor que amor se llama muy contrario es, según fama, de la razón y su bando, y esto veréis claro cuando amáis una linda dama.

Y así sigue. Las coplas van añadiendo detalles, o reforzando la argumentación. Explica el autor, ante todo, que el amor es ciego:

... de aquí se viene a entender que queréis una mujer con tan ciego entendimiento, que bebéis por ella el viento y ella a vos no os puede ver.

Esos tres navegantes "en obligación no están / de tener con razón cuenta"; "no hay obligación alguna / que contra amor nada pueda", de manera que

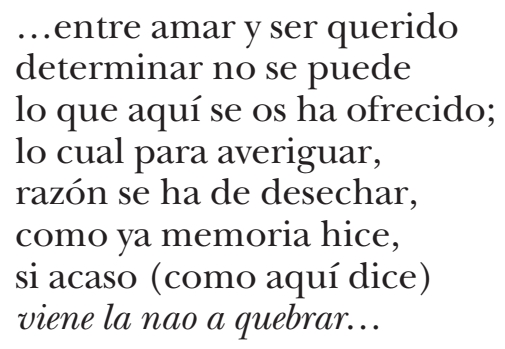

Queda, así, abrumadoramente demostrado que la razón debe ceder ante el amor (el amor del galán, por supuesto; el de la dama enamorada de él no se toma en cuenta); y la solución se impone: 
amor al que está obligado, ya está claro declarado cuál echaréis a la mar.

Unos decenios después, Francisco López de Zárate escribió un soneto con este epígrafe: "Un amante con dos damas en una borrasca, sobre si siendo fuerza echar una dellas en la mar sería la amada de él, o la que le amaba":

Ofender a quien ama, villanía a quien amo, ni a monstruos se concede, que esto ni proponerse, ni ser puede, porque lo deliró la fantasía.

Por lo justo no incurre en demasía el que al rigor más grande se concede, justo es verter (si la ocasión sucede) la vida al mundo por salvar la mía.

Que aquél peque, infeliz, en loco o fiera, apensionóle en fin la humana suerte que nos condena a todo lo posible;

éste, ni hombre, ni loco o bruto fuera, que nadie a su alma puede dar la muerte ni reducirle el caso a lo imposible ${ }^{15}$.

Es un soneto muy hermético. Mejor dicho, a mí me resulta endiablado. ¿Qué cosa, por ejemplo, es "verter la vida al mundo por salvar la mía"? Lo que de algo sirve es leer el soneto a partir del final, que interpreto así: 'Ningún hombre, por loco o bruto que sea, puede matar a su alma' (y el alma del enamorado es la dama a quien él adora) ${ }^{16}$.

Al epígrafe del soneto le puso algún lector esta apostilla: "Pregúntase a quién dellas [debe echar al mar]. Necia pregunta, debiéndose él echar antes”. Sí, sin duda, pero esto sería sa-

15 Francisco López de Zárate, Sesenta y seis poemas inéditos, ed. J. Simón Díaz, Logroño, 1976, pp. 39-40 (los poemas proceden de un manuscrito de la British Library, autógrafo según el editor); LARA-II, pp. 141-142.

16 El soneto, según LARA, “opone en magnitud de transgresión (ofensa, pecado) los posibles calificativos de una acción que sólo se atenúa con la muerte de la amante aborrecida", -explicación que encuentro tan hermética como el soneto mismo. Lo único claro es que quien acaba ahogada es la dama que quiere al galán y a quien éste aborrece. (¿Habrá leído bien Simón Díaz el manuscrito? La repetición de la rima concede en los versos 2 y 6 me parece sospechosa.) 
lirse por la tangente. El epígrafe dice que "es fuerza" echar una al mar, y cualquiera entendería que esa fuerza es la de la voz sobrehumana, pavorosa, ineluctable. Si la "fuerza" fuera la pequeñez del batel, entonces sí, el más elemental sentido de caballerosidad exige que el galán se eche al agua y se salven las dos damas.

Eliminada la voz pavorosa, puede Quevedo salirse airosamente por la tangente:

La que me quiere y aborrezco quiero librar, por que acompañe mi ventura, pues me aborrece en Floris la hermosura por quien amante y despreciado muero.

Mas ¿cómo? ¿Del amor en que ardo espero contra mi propia vida tal locura? La que yo adoro pasará segura: obligarála ver que la prefiero.

Mas si por no vivir desesperado soy ingrato, mi propio amor desprecio y contra mí aconsejo mi cuidado.

Si el uno por las dos ha de ser precio, más quiero ser amante y ahogado que al favor y al desdén ingrato o necio ${ }^{17}$.

Los cuartetos están impecablemente razonados. El primero dice: 'Ya que mi querida Floris me aborrece, salvaré a Clori [llamémosla así], que me quiere mucho, aunque yo la desprecie'. Y el segundo: 'No. Salvaré a Floris, que es por quien vivo' (aunque añade, no muy galantemente, una consideración utilitaria: 'Ya Floris sabrá agradecer'). Al final, como lo ha anunciado el epígrafe, "elige el morir amando, por no dar muerte a la amante o a la amada, hallándose en peligro de morir alguno"18. El penúltimo verso contiene el muy quevediano tópico de la in-

${ }^{17}$ Quevedo, Poesía original, ed. J. M. Blecua, Barcelona, 1963, núm. 322; LARA-I, pp. 130-132.

${ }^{18}$ Jusepe Antonio González de Salas, editor de Quevedo y autor del epígrafe, no explica qué cosa es el "peligro", pero añade una nota: Gregorio Silvestre le preguntó a Barahona de Soto (y, como en 1648 ya nadie conoce a estos dos poetas, explica quiénes fueron) "que si alguno fuese en un barquillo con dos mujeres, que a la una quisiese él y a la otra aborreciese, amándole ella, siendo forzoso echar una al mar, ¿cuál elegiría?” (Evidentemente, ni siquiera un erudito como González de Salas tenía, en 1648, noticia de Antón de Montoro.) 
mortalidad del amor ("nadar sabe mi llama la agua fría..."). Y así queda bonitamente eliminado el horror de las otras soluciones: la ingratitud al favor (de Clori) y la necedad de pasarse la vida sufriendo desdenes (de Floris).

El siguiente romance anónimo del siglo XVII, aunque muy "barroco", no necesita comentario (ni hay para qué copiarlo íntegramente):

Que arroje a Cintia o a Lisi, al fin, barquero, es preciso...

Tienen casi igual acción entrambas en mi albedrío: Cintia, porque lo granjea; Lisi, porque se lo rindo...

Obligaciones me acuerda Cintia, de amantes suspiros $\mathrm{y}$, entre memorias de ingrato, memorias de agradecido...

Si a Lisi arrojo, dos veces a la tiranía asisto, pues en ofender a Lisi también me ofendo a mí mismo...

¡Viva Lisi! - y contra Cintia, si pareciere delito, tengo un dios que me disculpe, con que de ingrato me libro ${ }^{19}$.

En 1639 Gerónimo de Porras copia en sus Rimas la vieja pregunta de Silvestre ("Servís con grande querer / a una muy hermosa dama...") y la contesta en tres décimas aún más barrocas que el romance anónimo:

Vaya al mar la que me ofende, cuando por mí se desvela; muera el fuego que me hiela, viva el hielo que me enciende ${ }^{20}$. Mas mi impulso reprehende una natural razón,

19 B.N.M., ms. 3889, ff. 116-117; LARA-I, pp. 129-130.

${ }^{20}$ Glosa (empleo, por comodidad, los nombres del romance anterior): 'Cintia me ofende (me importuna con su amor); su fuego me deja helado, mientras que el hielo del desdén de Lisi me inflama de amor'. (Se sigue que la destinada a salvarse es Lisi.) 
diciendo que es bruta acción, nacida de pecho injusto, querer, por que viva el gusto, que muera la obligación.

$\mathrm{Si}$, peña de nieve fiera, aquélla a mi amor rigores, y ésta a mi rigor amores rinde, Mongibel de cera ${ }^{21}$, que dé a la salada esfera a ser de los peces cebo quien me aborrece, no es nuevo, ni agravios injustos hago si a una lo que debo pago y a otra pago lo que debo.

Si es cierto que más agrado a Júpiter que a Cupido siendo cruel agradecido que piadoso interesado ${ }^{22}$, viva y logre su cuidado quien más me supo obligar, y muera la que ablandar no pude, y pues zahareña, ingrata en amor, fue peña, vaya a ser peña a la mar ${ }^{23}$.

Así, pues, quien se salva es Cintia, la dama que, a fuerza de amor, supo "obligar" finalmente al galán. De los poetas que han desfilado hasta aquí, el único que ha llegado a esa conclusión es Juan de Molina. (Quevedo no cuenta.)

A lo largo del siglo XviI se crearon en España y sus dominios varias "academias", efímeras por lo general; así, en Madrid, "la Peregrina" y "la Salvaje", entre otras. Había una junta semanal cuyo presidente proponía "asuntos" para la semana siguiente. En cierta academia se propuso nuestro asunto, y Luis de Ulloa Pereira cumplió con un soneto:

Voz de Oráculo fue que se entregara de dos ninfas, al mar, la que eligiera

${ }^{21}$ Glosa: 'Lisi es un témpano y Cintia un volcán [Mongibelo = Etna] que se derrite de amor por mí'. (Se sigue que la destinada a salvarse es Cintia.)

${ }^{22}$ Cupido (que representa al apetito amoroso) está por debajo de Júpiter (que representa evidentemente a la razón).

${ }^{23}$ Gerónimo de Porras, Rimas varias, Antequera, 1639, ff. 78-79; LARA-II, pp. 140-141. 
amante que, forzado, en la ribera

el castigo crüel ejecutara.

El caso fue que en una idolatrara, y otra en el hielo de su olvido ardiera.

Fue de razón librarse la postrera, y fue de amor que la razón faltara.

Premio fue, no castigo, que ofreciese túmulo un elemento a la fineza de la que ya murió cuando vivía; y al desdén, fue lisonja que tuviese confusión y escarmiento la porfía y disculpa y ejemplo la dureza ${ }^{24}$.

Yo encuentro este soneto casi tan impenetrable como el de López Zárate: me marea el torbellino de agudezas y paradojas: hielo, fuego, amor, desdén, olvido, premio, castigo, muerte, vida, lisonja ['halago'], confusión y escarmiento para la porfia, disculpa y ejemplo para la dureza. Al copiar y retocar el soneto en sus Memorias, el propio Ulloa, lector de sí mismo, debe haber sentido la conveniencia de ayudar a lectores como yo, y explica: "Echó a la que quería, quedándose con la que le amaba". (Es la misma solución que da Gerónimo de Porras.) No queda sino admirar la argumentación del primer terceto: hizo muy bien el galán en arrojar al agua a la dama de quien era tan amado; no fue castigo, sino premio a quien en vida estaba ya muerta de amor; sea, pues, su túmulo el océano infinito. (Aquí Ulloa hace pensar en el Quevedo de las hipérboles eróticas.)

Aparte de las academias establecidas había otras ocasionales, convocadas para celebrar (o llorar) algún acontecimiento. En una de éstas, reunida en Cádiz para un festejo de Carnaval, don Alonso Reinoso, canónigo de Sevilla, escribió el siguiente soneto sobre el tema consabido:

Dichoso tú, quien seas, que has podido verte dueño de todo tu cuidado, $y$ a fuerza de un rigor amenazado aliviar un tormento padecido.

Acalla el mar, pues quiere, embravecido, mitigar sus rigores sobornado;

24 Memorias de Ulloa Pereira, ed. M. Artigas, Madrid, 1925, pp. 114-115; es texto más satisfactorio que el impreso antes en Versos que escrivió D. Luis de Ulloa Pereira, Madrid, 1659. Los dos están en LARA-I, pp. 133-135 y nota 79. 
y si le has de arrojar lo más pesado, ¡oh, qué pesado que es lo aborrecido!

¿Qué dudas? Dale al golfo tu retrato;

no haya pena a tu pena parecida, y así te olvidará tu mala suerte.

Viva tu dueño (aunque es tu dueño ingrato), que, viendo que te debe a ti la vida, podrá ser que suspenda el darte muerte.

Pese a sus retorcimientos, no tiene este soneto nada de problemático. Lo raro es su hechura. El poeta felicita en el primer cuarteto al amante desdeñado, que ya está en posesión de la amada desdeñosa (fait accompli), y en el segundo, trasladándose al momento de la decisión, lo invita a deshacerse sin miramientos de la otra, la estorbosa (los versos 7-8 hacen pensar en el Quevedo cínico): vaya al mar la que es su "retrato" (pues es tan desdeñada como él lo ha sido). 'Sí -le dice al final-, la dama que salvaste no te quiere, pero "podrá ser" que algún día cambie' (lo cual se parece a lo que dice Quevedo en el verso 8 de su soneto).

El relator del festejo de Cádiz cuenta, con gran admiración, que don Alonso Cherino, al oír el soneto del canónigo, decidió llevarle la contra, y "en sus mesmos consonantes defendió a la aborrecida amante, sin más embarazo ni dilación que arrimarse a un bufete" y tomar pluma y papel:

No porque pesa más lo aborrecido la ingratitud reserves de lo amado, oh tú que, de una muerte consultado, el leño a redimir vas oprimido.

Con el tormento al tuyo parecido la pena adularás de tu cuidado, y servirá de lastre lo pesado para escapar mejor lo agradecido.

Mal agradecerá su misma vida quien a deudas de amor te mira ingrato y va una muerte a mejorar su suerte;

pues si eres de quien te ama el homicida, cuando la que amas sea tu retrato, le habrás de agradecer con otra muerte ${ }^{25}$.

${ }^{25}$ Carnestolendas de la ciudad de Cádiz: Pruevas de ingenio de don Alonso Cherino Bermudes, por el capitán don Juan Ignacio de Soto y Avilés..., en cuya casa se hicieron, Cádiz, 1639, ff. 38-39; LARA-I, pp. 135-137. 
También Cherino apostrofa al galán. Sin duda su soneto es más complicado que el del canónigo, pero es porque al intríngulis de los razonamientos se añade la violencia de los consonantes forzados. Me detengo sólo en el segundo cuarteto: ' $\mathrm{Si}$ tú, un desdeñado, salvas a la también desdeñada, se aliviará tu tormento; será ella una carga pesada, sí, pero el peso podrá servir de lastre para el equilibrio de la nave, y de ocasión para corresponder al amor que esa dama te ha tenido'26.

El asunto del galán y las dos damas tiene un amplio desarrollo en las novelescas Soledades de la vida de Cristóbal Lozano. Cada "soledad" es una novelita. En la cuarta, Lisardo cuenta cómo se enamoró de Isabela, la cual se mostraba muy esquiva (y con razón, pues, como averiguó Lisardo más tarde, estaba prometida a don Fernando, "caballero muy noble, más rico que yo", y guapo además); en cambio, la otra dama, doña Ángela, estaba enamoradísima de él, aunque él no la quería. Sucedió entonces, no una navegación, sino un accidente de carretera: el coche en que iban se desbarrancó y cayó en el río. "Considerando que en sacarlas juntas a las dos arriesgaba la vida de los tres", Lisardo iba ya a salvar a su querida Isabela cuando, "representándoseme en ella, no el amor que yo le mostraba, sino la ingratitud con que me correspondía, y al contrario, mirando en doña Ángela no mi desamor sino su voluntad, no mi desconocimiento sino su razón, solté a Isabela... y, abrazado solamente de doña Ángela, la saqué en salvo a la ribera”.

Este suceso, dice el novelista, dio motivo a no pocos debates entre los caballeros que lo supieron; "escribiéronse muchos poemas, en que cada uno fundó en justicia su parecer". Y copia en seguida uno de ellos, que consta de siete décimas:

${ }^{26}$ En El Joseph de las mujeres escenifica Calderón (Sexta parte de sus Comedias, edición de 1683, pp. 61-65) una academia celebrada en casa de la culta Eugenia y presidida por ella. Se presentan tres sonetos - de Sergio: "Que te sirva, Lisarda, me ha pedido..."; de Aurelio: "Licio, la obstinación de tu porfía...”; y de Melancia: "Dices, Laura, que Fabio está ofendido...”-y Julia canta "un tono nuevo". Las composiciones son comentadas por los asistentes; y, como aluden a los líos amorosos de los personajes, los ánimos se caldean al punto de que Sergio y Aurelio sacan las espadas; al oír el alboroto, el padre de Eugenia interrumpe la sesión y regaña a tutti quanti: “...¿No bastaba / que tales divertimientos / hayan quitado antes de ahora / a Eugenia el entendimiento, / sino a todos?" (Sólo un loco se interesa en esas frivolidades.) 
Un hombre embarcado, estando con dos damas, de las cuales una no olvida sus males y él la está en extremo amando, otra está en él adorando y él no la puede mirar: ¿qué hará si arrojar al mar una forzoso le fuere? $¿$ ¿dejar a la que le quiere o a la que él quiere dejar?

Y sigue el caso que sabemos. La solución coincide, desde el comienzo, con la de Lisardo. Basten unos versos de muestra:

Si una no querida quiere y otra no quiere querida, la justicia es conocida para el que discreto fuere...; pague amor que le han tenido y arroje amor mal pagado...

No hay agravios como ver un galán cómo, al compás que él adora y quiere más, menos le quieren querer...

Está bien que el galán dé "vida a quien quiere su vida, / muerte a quien quiere su muerte"; es más justo "no dejar viva a quien amo / que dar muerte a quien me ama" 27 .

También Calderón de la Barca sucumbió a la seducción del viejo tema y lo desarrolló más ampliamente aún que Cristóbal Lozano en Amado y aborrecido, una de las comedias de lujo que compuso para el real palacio (con dos coros de música y toda clase de "efectos especiales") y que se imprimió en 1657 en la Octava parte de comedias escogidas. De hecho, el "asunto" propiamente dicho no llena sino unas cuantas páginas, las finales de la comedia. Los actos I y II y casi tres cuartos del III son una cadena de aventuras y complicaciones. Dante amaba a Aminta y ahora ama a Irene; Lidoro amaba a Irene y ahora ama a Aminta (pero los amores de

${ }^{27}$ Las Soledades de la vida y desengaños del mundo (Madrid, 1658) tuvieron varias ediciones; LARA-I, pp. 138-141, cita por la de Barcelona, 1722, pp. 99108. (La obra más famosa de Cristóbal Lozano es el David perseguido, "historia sagrada paraphraseada con exemplos y varias historias humanas y divinas", que fue un éxito de librería desde 1652 hasta fines del siglo XvIII.) 
Lidoro no influyen gran cosa en el argumento); Aurelio no experimenta ninguna mudanza: es adorador constante de Irene; también Aminta es siempre firme en su amor a Dante. Hay apariciones ("en el aire") de las diosas Venus y Diana, que traen su pleito particular (Venus apuesta por el amory Diana por el desdén); hay dos terremotos; hay un caballo desbocado en que va Aminta (Lidoro la salva); hay un león a punto de atacar a las dos damas (Dante las salva a las dos, a Irene porque la ama y a Aminta porque ella lo ama); cae un rayo e incendia la torre en que están las damas (de nuevo Dante salva a las dos). La tempestad, con la voz misteriosa que ordena echar al mar a una de las damas, no es sino la última de estas variadas aventuras ${ }^{28}$. Ya al comienzo del acto III ha habido un anuncio. Durante una fiesta palaciega cantan los músicos cuatro veces esta redondilla:

\author{
¿Cuál más infeliz estado \\ de amor y desdén ha sido: \\ amar siendo aborrecido, \\ o aborrecer siendo amado?,
}

y la cuarta vez la redondilla es glosada en cuatro coplas reales: Irene y Dante contestan que lo peor es aborrecer siendo amado; Aminta y Aurelio, que amar siendo aborrecido. En el desenlace se sale Calderón por la tangente: Dante, sin atender a la voz misteriosa -y repitiendo lo que ya dos veces ha hecho-, salva a las dos damas, y se salva él mismo. Un final trágico está excluido, pues se trata de una comedia. Y, como en tantas otras comedias, es el rey quien decide quién se casa con quién: la constante Aminta con Dante, y el constante Aurelio con Irene. $\mathrm{Al}$ renunciar a Irene, Dante siente que es una dicha casarse con Aminta. ¿Cómo es posible que llames dicha el "casar con quien quieres menos"?, pregunta Malandrín (el gracioso), y Dante le responde, muy burguesamente: "Sí, que para dama es buena, / Malandrín, la que yo quiero; / para esposa, la que a mí / me quiere". (Lidoro, por cierto, se queda sin pareja.) Así, pues, en la contienda de las diosas vence Venus. Pero ya Diana planea su desquite, y se encarga ella misma de anunciarle al distinguido auditorio que muy pronto podrá comprobarlo en una nueva comedia, El pastor Fido, escrita por "tres ingenios" (Antonio de Solís, Antonio Coello y el propio Calderón).

28 En ella se concentra, naturalmente, el análisis de LARA-I, pp. 141-148. 
Retrocediendo unos siglos, vuelvo a la tensó provenzal. La Provenza de los trovadores se convirtió, de la noche a la mañana, en la metrópoli poética de Europa. A comienzos del siglo xv habla don Enrique de Villena con gran respeto de los poetas del Languedoc, los pioneros, y se hace lenguas de los certámenes que entablaban en sus "cortes de Amor" o "consistorios de gaya ciencia". (El arte de los trovadores merecía, en efecto, el nombre de ciencia; una ciencia no severa, sino gaya: alegre, amena, ingeniosa.) Pero no fue en España donde primero penetró la influencia provenzal, sino en Italia, con Boccaccio, que hace participar al héroe de su Filòcolo, al margen de la acción principal, en unas "cortes de Amor" napolitanas donde se debaten trece "cuestiones de amor", ingeniosas a cuál más.

El Filòcolo se tradujo al español más tardíamente que otras obras de Boccaccio. El traductor, Diego López de Ayala, le puso como título Laberinto de Amor (Sevilla, 1546), pensando, evidentemente, en los "enredos" de las trece cuestiones; y en efecto, la segunda edición se intitula precisamente Treze questiones muy graciosas (Toledo, 1549). Pero ya en 1513 se había impreso (en Valencia) un libro cuyo tema procede de las cuestiones II y V del Filòcolo. Se intitula Questión de amor de dos enamorados: al uno era muerta su amiga; el otro sirve sin esperança de galardón. Pregúntase quál de los dos sufre mayor pena. Fue un gran éxito editorial, y hubo traducción francesa (Le débat de deux gentilz hommes espagnolz sur le fait d'amour, 1541), pero nunca se supo el nombre del autor. La afición a la literatura de debates estaba muy generalizada ${ }^{29}$. Además, muchos europeos leían español. El librero Alfonso de Ulloa, establecido en Venecia, publicó allí, en 1553, una edición de la anónima Questión de amora la cual, con buen olfato comercial, añadió las Treze questiones de Boccaccio.

En el Florisel de Niquea, Parte tercera (1535), por otro nombre Rogel de Grecia, Primera parte, obra del infatigable Feliciano de Silva, se intercala una larga cuestión de amor. Hay en cierto reino dos príncipes hermanos, A y B, y en el reino vecino dos princesas hermanas, $\mathrm{C}$ y D; D es requerida por A, pero ella ama a B;

${ }^{29}$ La portada de la segunda impresión (Medina del Campo, 1577) del Inventario de ANTONIO DE VILLEGAS anuncia una atractiva novedad: la "Questión y disputa entre Aiax Telamón y Vlixes sobre las armas de Aquiles" (disputa narrada por Ovidio en el libro XIII de las Metamorfosis). 
B pretende a C, pero C quiere a A. Para poner freno a las guerras continuas causadas por estas encontradas correspondencias, los dos reyes parlamentan y deciden que cada princesa elija esposo y justifique su elección ante un consistorio formado nada menos que por Amadís de Gaula y Amadís de Grecia. Todo dependerá, pues, de la elocuencia de las princesas, de su capacidad de persuasión. La triunfadora se casará con quien elija, y la pareja heredará los dos reinos; la perdedora quedará presa junto con el otro príncipe, y de por vida, en una torre. Pues bien, las dos princesas eligen a un mismo príncipe, argumentado prolijamente su elección: una lo elige porque lo ama; la otra, porque él la ama. Tras dos días de arduas deliberaciones, los Amadises declaran vencedora a esta segunda princesa. La discordia, sin embargo, se resuelve felizmente; todos se casan, y Amadís de Gaula logra que a la pareja perdedora se le conmute la sentencia de prisión perpetua por un cómodo destierro en cierto reino que él posee. Naturalmente, se mudan las "voluntades" ( $\mathrm{C}$ acepta el amor de B, a quien antes había desdeñado, etc. ${ }^{30}$.

Los "casos de amor" son la materia misma de la Diana de Jorge de Montemayor. Hay amores no correspondidos, amores fingidos, amores estorbados por la fortuna y cortados por la muerte, etc. En el episodio final del libro I, dos pastoras y dos pastores sufren de encontradas correspondencias. Un día, por casualidad, coinciden "los cuatro discordantes amadores" en una floresta, situación indeciblemente dolorosa, "porque cada uno miraba a quien no quería que le mirase: yo [dice Selvagia] preguntaba al mi Alanio la causa de su olvido, él pedía misericordia a la cautelosa Ismenia, Ismenia quejábase de la tibieza de Montano, Montano de la crueldad de Selvagia, cada uno perdido por quien no le quería”. Es el dýseros de Ausonio (epigramas Hanc volo quae non vult y Hanc amo quae me odit), pero multiplicado por cuatro. La situación puede representarse esquemáticamente así (las flechas indican la dirección de la "voluntad" amorosa):

\begin{tabular}{ccc} 
Alanio & $\rightarrow$ & Ismenia \\
$\pi$ & \multicolumn{1}{r}{} \\
Selvagia & $\leftarrow$ & Montano
\end{tabular}

30 Cf. S. P. Cravens, "Amadís de Gaula reivindicado por Feliciano de Silva”, $N R F H, 48$ (2000), pp. 66-67. 
Pero el relato mismo no es esquemático. Montemayor es un verdadero artista, de inagotable inventiva. A esa situación nos ha llevado gradualmente, a través de variadas peripecias. Yallí, en la floresta, se celebra una especie de consistorio (aunque sin jueces). Los pastores, uno a uno, exhalan sus quejas, Alanio en octavas, Ismenia en coplas reales, Montano en un villancico y Selvagia en una canción castellana. El villancico de Montano dice así:

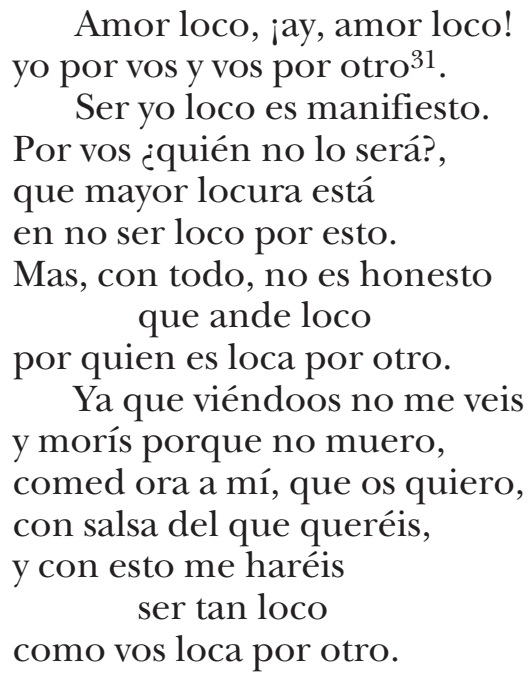

(La ocurrencia de Montano: 'Ya que te soy intragable, querida Selvagia, cómeme aunque sea con salsa de ese Alanio a quien quieres', hizo reír "muy de gana" a todos, pese a la gran "agonía” en que se hallaban.)

$\mathrm{Al}$ final del libro II hay tres villancicos ("cantares antiguos") glosados: Selvagia vuelve a quejarse de Alanio, y Silvano y Sireno se quejan de Diana, adorada por ambos y casada con otro. He aquí el villancico de Sireno:

Olvidástesme, señora: mucho más os quiero agora ${ }^{32}$.

31 Montemayor declara que estos dos versos son un "antiguo cantar". Margit Frenk, Corpus de la antigua lírica popular hispánica, Madrid, 1987, núm. 751, registra cinco glosas que de él se hicieron (una de ellas, de Camoens).

32 Parece que el cantar antiguo decía "Enojástesos, señora”, y que Montemayor lo alteró para adaptarlo a la situación. Cf. M. Frenk, Corpus..., núms. 399A y 399B. 
Sin ventura yo olvidado me veo, no sé por qué; ved a quién distes la fe y de quién la habéis quitado: él no os ama, siendo amado; yo desamado, señora, mucho más os quiero agora.

Paréceme que estoy viendo los ojos en que me vi, y vos, por no verme así, el rostro estáis escondiendo, y que yo os estoy diciendo: "Alzá los ojos, señora, que muy más os quiero agora”.

Hacia el final de la novela, cuando ya varios de los casos se han resuelto de diferentes maneras (o están en vías de resolverse), sólo estos tres pastores (Selvagia, Silvano y Sireno) siguen siendo desdichados. Pero también para ellos hay alivio: la maga Felicia les da a beber cierta agua encantada que tiene la virtud de "mudar las voluntades".

Leída durante muchísimos años, la Diana tuvo varias continuaciones y ejerció enorme influencia sobre la literatura posterior (y no sólo la de lengua española). Una de las primeras muestras de esa influencia es la Comedia llamada "Discordia y questión de amor", en la qual se trata, en subido metro y conceptos muy sentidos, la inconstancia de Amor y sus variables efectos, compuesta por Lope de Rueda. Su modelo es el episodio del libro I de la Diana que hemos visto. En la Discordia hay también cuatro pastores. En cierto momento se queja Petronio:

¡Oh Amor falso y lisonjero, malo y de mala nación! ¿Es posible, odioso y fiero, que a quien no quiero me quiera y no me quiera quien quiero?

Pero el mismo reproche a Cupido podría estar en boca de los otros tres querellosos. Con razón Baltasar Gracián, supremo teórico del Barroco español, asombrado al hallar esta complejidad en un "primitivo", encomia en su Agudeza y arte de ingenio (discurso XLV) al "prodigioso Lope de Rueda", autor de tan "ingeniosa invención". Elogia la "traza", pues "cuando parece 
que se desempeña, entonces se enreda más". En efecto, los pastores se topan justamente con Cupido, atado a un árbol por Diana (la Castidad), y lo liberan; Cupido, en agradecimiento, se ofrece a remediar a los pastores. Pero los deja desconcertados y aterrados cuando, para poner en práctica su oferta, les hace esta pregunta, puramente profesional: “¿Cuál queréis que mude aquí: / las pastoras o pastores?”. La situación es:

$\begin{array}{ccc}\text { Petronio } & \rightarrow & \text { Silvia } \\ \pi & & \searrow \\ \text { Leonida } & \leftarrow & \text { Salucio }\end{array}$

A la pregunta de Cupido, los pastores proponen esta mudanza:

\begin{tabular}{|c|c|}
\hline Petronio & $\stackrel{\vec{t}}{\leftarrow}$ \\
\hline Leonida & $\leftarrow$ \\
\hline
\end{tabular}

pero las pastoras, naturalmente, rechazan semejante solución y proponen esta otra:

$\begin{array}{cc}\text { Petronio } & \text { Silvia } \\ \forall \pi & \sqcup \boldsymbol{y} \\ \text { Leonida } & \text { Salucio }\end{array}$

y, en resumidas cuentas, todos se niegan a "mudar la afición", pues todos - ellas y ellos- se precian de leales y constantes amadores. Al final entonan un dolorido cantar:

Buscando venimos remedio de amores: ¡volvemos peores!... ${ }^{33}$

La "cuestión” de Lope de Rueda fue compendiada por Gaspar de la Cintera en una canción castellana cuya cabeza dice:

${ }^{33}$ Lope De Rueda, Comedia llamada "Discordia y questión de amor"..., ed. F. R. de Uhagón, Madrid, 1902. La única edición antigua que se conoce es de Barcelona, 1617, pero debe de haber habido otra u otras anteriores. Ésta es quizá la última de las obras que escribió Lope de Rueda, muerto en 1565 (seis años después de la primera edición de la Diana). 
Bras muere de amores de Ana;

Juana le tira del sayo;

Pelayo muere por Juana,

y Ana muere por Pelayo.

Gaspar de la Cintera, natural de Úbeda y vecino de Granada, donde se ganaba la vida con su oficio de coplero, era ciego. Cantaba sus composiciones, acompañándose de vihuela, en las calles y plazas, y sus versos se imprimían en populacheros "pliegos de cordel" que, no protegidos por algún derecho de autor, eran reimpresos aquí y allá: en Sevilla y en Córdoba, en Valladolid y en Burgos ${ }^{34}$. Si estaba "privado de la vista", según declara siempre en los encabezamientos, tenía en cambio un oído finísimo (como les sucede a tantos poetas y músicos ciegos que ha habido y hay). Su coplilla es la quintaesencia perfecta de la Discordia y questión de amor. Al gran acierto de dar nombres pastoriles "reales" a los cuatro amantes (Bras y no Salucio, etc.), añade el artificio de la rima encadenada, una de las "galas de trobar" tratadas por Juan del Enzina en su Arte poética: la primera palabra de un verso rima con la última del verso anterior. El encadenamiento métrico le viene como anillo al dedo al encadenamiento conceptual. El verso 2, que podría parecer ripioso (necesidad de rima para Pelayo), es todo un hallazgo: expresa muy gráficamente la urgencia amorosa de Juana (y, por extensión, la de los otros). La cuarteta va seguida de cuatro coplas de glosa que, si no añaden nada al argumento, lo amplían graciosamente. He aquí las dos primeras:

Bras por Ana da la vida,

y Juana a Bras se la ofrece;

Pelayo a Juana encarece

que le da pena crecida;

Ana a Pelayo, afligida,

le dice: "Crüel pastor,

págame amor con amor,

pues te viene ancho este sayo".

Bras quiere infinito a [Ana]

y Ana por Pelayo llora;

${ }^{34}$ Sólo dos de los pliegos sueltos de Cintera que registra Antonio Palau en su Manual del librero están impresos en Granada (por Hugo de Mena), uno en 1566, el otro sin fecha. Sabida es la suerte de los pliegos de cordel. Antonio Rodríguez-Moñino calculaba que de cada diez que se imprimieron, apenas uno habrá sobrevivido. 
y Pelayo a Juana adora, y a solo Bras quiere Juana; cada cual ama de gana al mismo que le aborrece; responde qué te parece deste trueco de Gil Bayo... ${ }^{35}$

Hacia la misma época, el joven Joaquín Romero de Cepeda, natural de Badajoz, reelaboró la Discordia de Lope de Rueda en una comedia intitulada Metamorfosea. Añadió a la cadena de amadores desdichados otros dos eslabones y dio a los pastores nombres muy cultos:

$\begin{array}{ccccc}\underset{\text { Eleno }}{\pi} & \rightarrow & \text { Belisena } & \rightarrow & \text { Medoro } \\ y \\ \text { Albina } & \leftarrow & \text { Aliso } & \leftarrow & \text { Rosina }\end{array}$

La Metamorfosea se llama así porque, en efecto, al final las "voluntades" de los seis pastores sufren una metamorfosis (dolorosa) ${ }^{36}$.

35 Coplas y chistes muy graciosos para cantar y tañer al tono de la vigüela, agora nuevamente hechas por Gaspar de la Cintera, privado de la vista, natural de Úbeda y vecino de Granada, pliego suelto de Burgos, sin año. Tomo el texto de B. J. Gallardo, Ensayo..., t. 2, cols. 458-459. Véase A. Rodríguez-Moñino, Diccionario de pliegos sueltos poéticos (siglo XVI), Madrid, 1970, núm. 149. PALAU (Manual del librero) registra una edición de Valladolid, 1580. En la segunda copla pongo "a [Ana]" en vez de "a mí" (para rimar con Juana). Dice Gallardo al final: "Véase el cancionero manuscrito de Mauro del Almendral, donde [la canción] se lee más correcta”, pero no da las señas de este manuscrito. Me pregunto si no será el editado por Margit Frenk y colaboradores con el título de Cancionero sevillano de Nueva York (Sevilla, 1995). Se sabe, en efecto, que este manuscrito perteneció a Gallardo, y en él está dos veces (núms. 75 y 572) el "Bras muere de amores de Ana..." con diferentes glosas. (Los versos 3-4 dicen las dos veces: "Pelayo por los de Juana, / Ana por los de Pelayo".) La cuarteta fue muy popular: está también en el manuscrito Esp. 373 de la Biblioteca Nacional de París, f. 70, y fue glosada asimismo por PERO DE ANDrAdE Caminha, Poesias inéditas, ed. J. Priebsch, Halle, 1898, núm. 421 (el verso 2 dice "Juana le traba del sayo").

36 De la Metamorfosea no tengo más noticia que la muy escueta que da Gallardo (Ensayo, tomo 4, col. 256), el cual apunta: "amores encontrados..., de que se arma un enredo que el ingenio [o sea el autor] tiene la crueldad de no desenredar al fin de la pieza"; y luego: "[al final] se truecan las suertes, pero con poca dicha de los enamorados". Dice también: "Este asunto está donosamente tratado en una canción de un compatriota de Romero [o sea de Badajoz], Mauro del Almendral, de quien he disfrutado un 
En una égloga de Pedro Laínez, "Tirsi, pastor del más famoso río...", los pastores son también seis (y tienen asimismo nombres cultos). Es un poema de 150 endecasílabos sueltos, en su mayor parte quejas de Tirsi por el desamor de Dafne; pero hacia la mitad habla también Clori, que adora a Tirsi y llora su falta de correspondencia:

‥¿YY tú, crüel, el justo amor debido a tu Clori tan mal en Dafne empleas?

Mas así va. ¿Son éstos los misterios de la diosa crüel que reina en Cipro, que desiguales ánimas y formas se deleita enlazar con crudo juego?

Alcipe ama a Damón, Damón a Clori, arde Clori por Tirsi, Tirsi ingrato por Dafne, Dafne está entregada a Glauco, en Glauco no hay amor...

La cadena, pues, se rompe en Glauco, que no ama a nadie ${ }^{37}$.

El anónimo autor de una "competencia y quistión de amor entre dos pastores ygualmente faborescidos de una pastora" se limita a lo esencial: pone en escena a una pastora, Florencia, y a sus adoradores, castizamente llamados Juan y Gil. Los demás pastores - a los cuales se suma el dios Cupido-se empeñan en que Florencia se declare por uno u otro amante, y ella siempre sale con evasivas, hasta que al final declara:

De Juan quiero ser querida y de Gil aborrecida; quiero a Gil, no que él me quiera, y Juan sí, más que a su vida ${ }^{38}$.

cancionero manuscrito". (La Metamorfosea se imprimió en las Obras de Romero de Cepeda, Sevilla, 1582, junto con otras "primicias" de su ingenio.)

37 Esta égloga se atribuye a Francisco de Figueroa en la edición tardía de sus obras por Luis Tribaldos de Toledo (Lisboa, 1626, pp. 49-53), pero el verdadero autor es Pedro Laínez, según hace ver Christopher MAurer, "Hacia una nueva edición de Francisco de Figueroa”, BBMP, 60 (1984), pp. 194-198.

38 Cancionero de cosas de amor, ms. 3806 de la B.N.M., según noticia de LARA-I, p. 125, nota 53. 
Ausonio fue muy leído y muy imitado en los siglos de oro (mucho más de lo que dice Menéndez Pelayo en las páginas de la Bibliografía hispano-latina clásica que le dedica), pero no muy traducido. De los cinco epigramas mencionados en las pp. 8385 no conozco sino estas versiones:

1) Aut restinguere ignem..., traducido por el portugués Andrade Caminha, poeta cortesano, a mediados del siglo xv:

Ou este áspero fogo, Amor, abranda, em que está sempre ardendo este meu peito, ou a outro frio peito, Amor, o manda, para que faça nele o mesmo efeito.

Se não basta a esta troca este meu rogo, faze igual em dois peitos este fogo! 39

2) Hoc quod amare vocant..., traducido por Salazar y Torres, el poeta admirado (y continuado) por sor Juana:

Esto que llaman amar

mezcla o desata, ;oh Amor!

O no abrases a ninguno, o en la llama abrasa a dos ${ }^{40}$.

3) Hanc volo quae non vult y Suasisti, Venus..., traducidos y fundidos en un solo poema por el ya citado Gerónimo de Porras ("Interlocutores, Venus y Marco"). Vale la pena leerlo entero:

-Quiero a ésta, que me aborrece; porque me quiere, aborrezco a aquélla. Remedio ofrece, si puedes, $y$ te enternece, Venus, el mal que padezco. -Eso es muy fácil: yo haré, trasmutando voluntades, que ame ésta, y aquélla que aborrezca. - Así tendré las mesmas dificultades.

39 Pero de Andrade Caminha, Poezias, ed. de Lisboa, 1791, pp. 303-304. (Obsérvese que no se dirige a Dione, sino a Cupido.)

40 Agustín de Salazar y Torres, Cýthara de Apolo, Madrid, 1681, p. 44. 
-¿Quieres amar las dos? -Sí, como en recíproca llama me correspondan. -Así, pues, el remedio está en ti: para ser amado, ama.

-Dame otro consejo, acaba, que a otras dos que me incendían así las solicitaba, $y$, al paso que las amaba, al mesmo me aborrecían.

-Véncelas con dones. -Soy un retrato, en lo desnudo, de Amor, y qué darles hoy no tengo, si no les doy de mi paciencia un escudo.

-Promételes oro sobre tu palabra. -Mal me inspiras: promesas serán de un robre, porque en la boca del pobre son las verdades mentiras. -Pon a Júpiter sagrado por fiador, con juramentos. -No es engañarle acertado, que sacaré, fulminado, de un rayo los escarmientos.

-Ronda sus puertas, porfía con su dureza. -Aunque peno en la ardiente llama mía, temo de la noche fría los peligros del sereno.

Escríbeles amorosas elegías. -Dificulto el ver y el beber gustosas las aguas que, numerosas, desata el Parnaso culto.

-Rompe sus puertas airado. -Temo de la ley la pena, y no quiero, desdichado, ver el cuerpo aprisionado, ya que el alma está en cadena.

-¿De amor, y no por amor, quieres morir, necio? - Creo que es sufrir mucho mejor desdichas, sin ser actor, que sufrirlas, siendo reo. 
-Lo que puedo y que está bien

te advierto. De no admitillo, a otros consulta. - Di a quién.

-Fedra o Elisa te den su cordel o su cuchillo;

o al mar, desde los que más escollos mira elevados Léucada, te arrojarás.

- ¿Este consejo me das?

- Tal se da a los desdichados ${ }^{41}$.

Las tres primeras quintillas son traducción bastante fiel del Hanc amo; pero las otras diez son más bien paráfrasis del otro epigrama, adornada con detalles pintorescos. El poeta no puede renunciar a las agudezas barrocas (como en las décimas del galán y las dos damas, supra, pp. 95-96): estar tan desnudo como Cupido; dar de limosna un escudo no de oro, sino de paciencia; tener el cuerpo aprisionado y el alma en cadena, las dos elaboradas maneras de decir 'No soy poeta' y la erudita alusión a Safo. (En cambio, Porras se deja en el tintero a Cánace y a Filis, dos de las cinco suicidas de Ausonio.)

Pero los poetas no necesitaban traducciones, ni tampoco leer a Ausonio en latín, pues el Hanc amo se había convertido en un tópico, posesión de todos (locus communis), como se ve en esta redondilla del portugués Rodrigues Lobo:

Tenho um bem que mal me trata; não me entendo com ninguém: fujo de quem me quer bem, quero bem a quem me mata,

conflicto que él mismo resuelve después:

Amor, já desenganei um cuidado que trazia, pois me fugiu quem seguia, fujo de quem já busquei ${ }^{42}$.

41 Gerónimo de Porras, "Amando un galán una dama porque le aborrecía, y aborreciendo otra porque le amaba, pide remedio a la diosa Venus. Traducción de la epigrama de Ausonio Hanc amo...", etc., en sus Rimas varias, Antequera, 1639, ff. 85-87.

42 Francisco Rodrigues Lobo, O pastor perigrino (Segunda parte da sua Primavera), Lisboa, 1608, ff. 72v y 97r. A las redondillas-que, como se ve, no 
Antonio de Villegas, parafraste de la Heroida VII de Ovidio (carta de Dido a Eneas), suele cerrar con agudezas las redondillas de su paráfrasis. Así ésta:

Aquí por tenerte lloran, allá la muerte te ofrecen: buscas los que te aborrecen por dejar los que te adoran ${ }^{43}$.

(O sea que Eneas cambia el amor que Dido le tiene en Cartago por el odio con que lo van a recibir los moradores de Italia.)

Guillén de Castro se refiere a otro conflicto de Dido, que, al huir su adorado Eneas, se ve destinada a casarse con el aborrecido Yarbas:

¿Qué haré? ¿Qué mujer se ha visto en fortunas tan contrarias, de dos hombres ofendida, pues, con desiguales armas, el que adoraba me huye y el que aborrezco me alcanza?44

En La devoción de la cruz, comedia religiosa de Calderón, dice Julia:

$\mathrm{Al}$ que me desprecia, busco.

¿Quién vio tan dudoso efecto

están contiguas- siguen glosas en coplas reales. Pero la antítesis no es perfecta. La primera dice: 'Aborrezco a quien me ama y amo a quien me aborrece', y la segunda: 'Como ahora quien me amaba me aborrece, puedo ya aborrecerla tranquilamente' (¿habrá que entender que quien lo aborrecía ahora lo ama?). -Otro ejemplo portugués: "Amais a quem vos não quer, / não quereis a quem os ama...": The Hispano-Portuguese Cancioneiro of the Hispanic Society of America, ed. A. L.-F. Askins, Chapel Hill, 1974, f. 59v del manuscrito.

43 Inventario de Antonio de Villegas [1565], ed. de Madrid, 1955, t. 1, pp. 72-78. Esta paráfrasis se halla también en el manuscrito Esp. 307 de la Biblioteca Nacional de París, ff. 150-154.

${ }^{44}$ Guillén de Castro, Dido y Eneas, acto III. Pero aquí hay contaminación del Hanc amo con otro epigrama atribuido a Ausonio, Infelix Dido: "Dido infeliz, no bien eres / dada a marido ninguno: / huyes cuando muere el uno, / y cuando huye el otro, mueres" (traducción de Bartolomé Leonardo de Argensola). En efecto, Dido huye de Fenicia al morir Siqueo, y muere en Cartago al huir Eneas. 
de amor? Cuando me rogaba con mil lágrimas Eusebio, le dejaba; pero agora, porque él me deja, le ruego. Tales somos las mujeres, aun contra nuestros deseos. Ninguno nos quiera bien si pretende alcanzar premio, que, queridas, despreciamos, $\mathrm{y}$ aborrecidas, queremos ${ }^{45}$.

En un cancionero toledano hay una composición dialogada, "Sálveos Dios, graciosa dama...", donde se lee:

En mí mora una pasión que atormenta el corazón con un mal fiero:

que a quien no me quiere quiero, y es el placer

que he dejado de querer a quien me quiere ${ }^{46}$.

En una de las ocho novelas que constituyen su Teatro popular cuenta Lugo y Dávila que el héroe, caminando a media noche por las calles silenciosas de Madrid, oye de pronto una dulce voz que canta:

Niño mal contento, Amor, da a la voluntad desdén: que donde le quieren bien, allí ejecuta el rigor...

Allí se muestra enemigo donde es justo acariciar, porque a lo que ha de premiar da riguroso castigo. Yo, triste, en quien más obligo menos obligación veo; donde aborrecer deseo, vive inmortal el querer. ¡Venus, entra a componer pleito en que el actor es reo!... ${ }^{47}$

45 Calderón de la Barca, La devoción de la cruz, acto II, vv. 1662 ss.

46 B.N.M., ms. 17.698, f. 93v.

47 Francisco Lugo y Dávila, Teatro popular: Novelas morales para mostrar los 
El sevillano Juan de Salinas glosó esta "letra ajena":

Púsoseme el sol, salióme la luna;

más me valiera, madre,

la noche escura

con una "letrilla propia", que comienza:

El que yo quería, madre, no me quiere; y por mí se muere

el que aborrecía... ${ }^{48}$

Gabriel Bocángel tiene un romance que parece respuesta a una pregunta de academia, "Si un amante [Fileno] se ve escogido de dos damas, una [Filis] que amada le aborreció, y otra [Laura] que le amó aborrecida, ¿a cuál debe más?":

Amar por obligación es tributo, no es empleo; hipócritamente hace agradecidos el miedo.

Laura me hiela en su ardor; salamandra soy de hielo, que la repito en cenizas muchos cuidados de fuego.

Helada Filis me abrasa, vista y amada, tan luego, que pudieron ser dos cosas, pero ninguna primero...

Es decir: si Fileno escogiera a Laura, que lo quiere, pero a quien él no quiere, sería "obligación", no genuino "empleo" (o sea amor); Laura lo deja helado; quien fulminantemente lo

géneros de vidas del pueblo, Madrid, 1622, ff. 66-67. Son cuatro décimas; copio sólo la segunda y el comienzo de la primera. (El Teatro popular fue reeditado por E. Cotarelo y Mori en la "Colección de antiguas novelas españolas", Madrid, 1906.)

48 Henry de Bonneville, Le poète sévillan Juan de Salinas (1562?-1649). Vie et cuvre, Paris, 1969, pp. 324-325. Dice Bonneville que la "letra ajena" está en el Ramillete de flores, Quarta flor de romances, Lisboa, 1593. Cf. también su edición de las Rimas humanas de Salinas, Madrid, 1987, núm. 43. 
abrasa es Filis, que no lo quiere. Por fortuna, en cierto momento hizo Filis algo heroico: mudó su voluntad, violentando su inclinación, o sea rompiendo el decreto del destino (cosa que Laura ha sido incapaz de hacer). La conclusión se impone:

Perdóname - dije-, ¡oh Laura!, si Filis nació mi dueño...

Filis, amándome, rompe de inclinación el decreto; tú le sigues. Juzga agora a quién debe más Fileno ${ }^{49}$.

Salcedo Coronel, editor y comentarista de Góngora, también elige el romance para dirigirse "A Lisi, persuadiéndola que le quiera y deje a quien la aborrece”. Dice así la tercera cuarteta:

A quien te aborrece adoras $\mathrm{y}$ a quien te adora desprecias. ¿Qué pocas veces quien ama halló igual correspondencia! 50

Tal vez sea respuesta a una "cuestión" de academia el romance de Saavedra Guzmán intitulado "Quiere a quien le desprecia y desprecia a quien le quiere" 51 . Tal es el caso de Vicente Sánchez. "Diéronle esta redondilla para glosarla":

A quien quiero no me quiere, y a quien me quiere no quiero. ¡Muera Amor de lo que muero, pues muero de lo que muere!,

y él la glosó en cuatro décimas ${ }^{52}$.

49 Gabriel Bocángel y Unzueta, Obras, ed. R. Benítez Claros, Madrid, 1946, pp. 91-92.

50 García de Salcedo Coronel, Obras, Madrid, 1627, ff. 150-151.

51 Martín Saavedra y Guzmán, Ocios de Aganipe, Trani, 1634, pp. 90-91. (El autor vivía en Italia y alude a cosas italianas, aunque de pronto le llegan saudades de cierta Geromilla que se bañaba en el Manzanares. ¿Tendrá que ver con el autor de El peregrino indiano, Antonio de Saavedra Guzmán, "en México nacido", que a fines del siglo xvi salió de la Nueva España para nunca más volver?)

52 Vicente SÁnchez, Lyra poética, Zaragoza, 1688 (edición póstuma), p. 91. 
El curioso Pedro de Quirós, "religioso de los clérigos menores de Sevilla" pero bastante aficionado a los versos mundanos, llegó al colmo de la brevedad al contar la historia:

Siguióme Filis, huí; seguí yo a Filis, huyó. ¡Oh, si mi no fuera sí! ¡Oh, si mi sí fuera no! 53

Si acaso el debate es un "género literario", será quizá, junto con el enigma, el género más antiguo, tan antiguo como el lenguaje: debate y enigma existen por la sencilla razón de que todos los seres humanos tienden por naturaleza a saber, como dice Aristóteles en la primera línea de su Metafisica. El debate literario tiene el mismo infinito campo de acción que los debates de la vida real. Y cada escritor debate como se le antoja. No hay necesidad de legislar sobre la manera de debatir. Juan Díaz Rengifo ni siquiera menciona el "debate" en su Arte poética, impresa por vez primera en 1592. Por eso resulta ligeramente cómico ver cómo el catalán Josep Vicens, en su edición aggiornata del Arte de Rengifo, publicada ya en el ocaso de la literatura áurea (Barcelona, 1703), llena la laguna con un capítulo que añade, intitulado "De los problemas". Lo más gracioso es su tono doctoral. Es como si Vicens se sintiera un pionero pisando terreno virgen. "Este nombre, problema - dice en su castellano algo torpe-, significa una proposición que contiene una pregunta dudosa, y esto suele ser de dos cosas semejantes, que se pueda defender cualquier parte de las dos, a manera de una thesis; las cuales, aunque se pueden defender con una oración suelta [o sea en prosa], es más plausible en la poesía”. Hay proposición, hay argumentos en pro (legitimidad, justicia, utilidad, honestidad, todo "con la brevedad más posible"); hay refutación de los argumentos contrarios ("y todo esto se hará mejor comprobándolo con exemplos, sentencias y opiniones de autores muy fidedignos"); hay, finalmente, "un breve epílogo". Y, como ejemplo, publica íntegras las dos opiniones que se expresaron

53 Poesía divina y humana..., apud Gallardo, Ensayo, t. 4, col. 21; también $B A E$, t. 32, p. 423. 
en una academia de Barcelona sobre esta peliaguda cuestión: "Si fue más cruel Tholomeo Fisco, rey de Egipto, matando a su hijo Nenfitén, o si lo fue Nerón quitando la vida a su madre Agripina". Manuel de Cárdenas "tuvo a cargo" defender esta segunda opinión, pero los jueces fallaron en favor de Carlos de Guzmán, que defendió la otra: el hijo de ese extraño Tholomeo Fisco no tenía tacha, mientras que Agripina era una mujer disoluta: razón había para eliminarla ${ }^{54}$.

La sola lista de los productos literarios en que hay "cuestiones" y "debates", o que consisten precisamente en eso, sería inacabable. Dos de los primerísimos poemas líricos castellanos son la disputa del Clérigo y el Escudero (Elena y María) y los "denuestos" del Agua y el Vino que hay al final de la Razón de amor ${ }^{55}$. Juan de Mena escribió un "Debate de la Razón contra la Voluntad", y su seguidor fray Íñigo de Mendoza una "Historia del questión y diferencia ['pleito'] que hay entre la Razón y la Sensualidad" (cf. Lara-I, nota 46). Francisco de Aldana hizo un "Soneto de cuál de los dos goce más en el cielo, el Entendimiento o la Voluntad"; el agustino fray Jerónimo de Saona añadió a sus Discursos predicables (Barcelona, 1598), haciéndolo notar en la portada, unas "Questiones positivas y scolásticas 56 sobre quál fue más amado del Señor, sant Pedro o sant Joan Evangelista”. Antonio Hurtado de Mendoza, contemporáneo de Quevedo, escribió una décima "Probando ser mejor desgraciado discreto que necio virtuoso", en seguida otra en que "Prueba lo contrario", y otra más en que "Prueba contra lo uno

${ }^{54}$ Las dos respuestas están hechas con un mismo esquema de canción petrarquista (seguramente así se pedía en la convocatoria). Son versos muy mediocres, pero Vicens los publica con visible satisfacción porque, en una época de marasmo casi total de las letras catalanas, él cree que la salvación es escribir en castellano. ¡Esos versos se compusieron en "la Academia de Federico", en Barcelona! Por lo demás, Vicens era incapaz de poner ejemplos más bonitos de problemas: no da señales de mucha familiaridad con la poesía española. Véase A. Alatorre, "Para la historia de la cultura literaria en Barcelona: el testimonio de Josep Vicens (1703)", Anuari de Filologia, Universitat de Barcelona, 21 (1998-99), 21-37.

55 Enrique Díez-Canedo y Alfonso Reyes hicieron una divertida parodia de estos "denuestos": "Debate [o altercatio] del Vino e la Çerueza": Alfonso ReYEs, Burlas literarias, México, 1947, pp. 29-43.

${ }^{56}$ El padre Calleja, biógrafo de sor Juana, pondera el "rigor escolástico" de la Crisis sobre la gran cuestión de cuál fue la mayor fineza del amor de Cristo por los hombres. 
y lo otro" 57 . En la novela Clareo y Florisea (1552) de Alonso Núñez Reinoso, el Duque de la Ínsula de la Vida se entretiene, después de la cena, con "quistiones y burlas agraciadas y discretas" en compañía de sus cortesanos, y en una de esas cultas sobremesas Melisena hace preguntas y Rosalindo las va contestando: "cuál es más dificultoso, fingir amor con no tenello o encubrillo con tenello" (respuesta: lo segundo); "qué se debe tener en más: una dama hermosa y no avisada [no bien dotada intelectualmente], o discreta y no hermosa" (respuesta: vale más la discreta, que tiene hermosa el alma); "si puede haber amor sin celos" (respuesta: no), etc. ${ }^{58}$ La pregunta de qué cosa es peor, la ausencia o los celos, se repite hasta el cansancio en los siglos de oro. Abundan también los poemas -sonetos sobre todo- hechos para redargüir a otros; así el romance que hizo sor Juana para contradecir a José Pérez de Montoro, cuya tesis era que en el amor perfecto no caben los celos. Y este ejemplo nos dice mucho sobre la índole de los debates: sor Juana estaba de acuerdo con Montoro; si le llevó la contra fue por obediencia a una "insinuación" de la condesa de Paredes. Es, ni más ni menos, el arte de los sofistas de tiempos de Sócrates: inducir la persuasión es sólo cuestión de savoir dire, de técnica retórica.

Campo ideal para los debates son las academias. En la madrileña del Retiro, celebrada en 1637, se debatieron (según LARA-I, nota 76) problemas como qué es peor: ser necio algunas veces, o ser siempre muy discreto, o quién es mejor galán: el de buen físico o el de finos modales. En otra academia madrileña hay una serie de preguntas y respuestas que se relacionan vagamente con el Hanc amo. He aquí la primera pregunta:

\author{
-Clori, por Fabio muriendo, \\ no puede con él gozarse \\ sin reducirse a casarse \\ con quien está aborreciendo: \\ por gozar a quien adoras, \\ Fili, entre año raras veces, \\ ¿fueras de quien aborreces \\ todas las noches seis horas?
}

${ }^{57}$ Josef Alfay, Poesías varias de grandes ingenios españoles (1654), ed. J. M. B[lecua], Zaragoza, 1946, núms. 78-80.

58 Novelistas anteriores a Cervantes (tomo 3 de la BAE), pp. 442-443. 
La respuesta de Fili -que sabe, obviamente, que la mujer casada tiene más libertad que la que vive bajo custodia paterna- no podía ser más cínica:

\author{
- Casándome, el que aborrezco \\ "suya" con razón me llama; \\ y, sin casarme, la llama \\ me consume en que padezco. \\ Cásome en fin, que el dolor \\ poco es, se templa, se cura \\ en la esperanza segura \\ de gozarme con mi amor; \\ y mayor gloria consigo \\ en la que gozar pretendo, \\ pues la aumento destruyendo \\ el honor de mi enemigo.
}

O sea que tendrá una satisfacción supererogatoria: ponerle los cuernos a ese odioso marido ${ }^{59}$.

Termino esta sección con dos composiciones "extravagantes" (fuera de serie, por así decir). La primera, de hacia 1568, desarrolla el tema del amante torturado que desea morir para no sufrir más, tema que aparece, famosamente, ya en el Cancionero general de 1511: "Ven, Muerte, tan escondida, / que no te sienta venir, / por que el placer de morir / no me torne a dar la vida"60. La Muerte es una ausoniana amada desdeñosa, a quien el anónimo poeta acosa a súplicas:

59 Kenneth Brown, "Gabriel de Corral: sus contertulios y un manuscrito poético de academia inédito", Castilla, Universidad de Valladolid, 1982, núm. 4, pp. 9-56. "Son estas obras de D. Gabriel de Corral", dice una nota del manuscrito (el 4051 de la B.N.M., f. 658); pero, como demuestra Brown, son en realidad de Pedro Méndez de Loyola, menos conspicuo que el autor de La Cintia de Aranjuez. Las academias solían tener público, y entre los aficionados a la culta exhibición solía haber damas, pero la reseñada en el manuscrito se hizo "para hombres solos", pues iba a haber preguntas/respuestas aún más subidas de color: 1) Antandra, mujer pobre, cuenta con un viejo que remedia su hambre y con un mozo que remedia su ardor: se le pregunta a Celia con cuál se quedaría, y ella responde que con el segundo ("vaya el viejo y venga el mozo, / que no ha de faltarnos pan”); 2) Lesbia tiene dos galanes, uno con el miembro grueso pero corto, y el otro con el miembro largo pero delgado; se le pregunta a Celia cuál escogería, y ella dice que el segundo (“...que es lo importante del gusto / que alcance a dar en lo vivo").

60 Así se lee la cuarteta en el Cartapacio de Francisco Morán de la Estrella (hacia 1585), ed. R. A. DiFranco et al., Madrid, 1969, núm. 649, y va seguida de una glosa en cuatro coplas reales. 
Si del que te quiere más, Muerte, pretendes huir, yo no me quiero morir: quizá con esto vendrás.

$\mathrm{Si}$ al que te quiere no quieres, si huyes del que te llama, si aborreces al que te ama y por quien no te ama mueres, yo, Muerte, más que el que más te tengo de perseguir; yo no me quiero morir: quizá con esto vendrás [...].

Si del que te sigue huyes $y$ al que de ti huye sigues, si al que te teme persigues y al más contento destruyes, ya no te quiero jamás, siempre di en te perseguir; ya no me quiero morir: quizá con esto vendrás $[\ldots]^{61}$.

La otra composición es un soneto estrambotado de Antonio de Solís, poeta algo anterior a sor Juana. El galán del soneto, a semejanza del amante ausoniano del Hanc amo y del Suasisti, Venus, no ve inconveniente en amar a $\operatorname{dos}^{62}$ :

Amar a dos, y a entrambas con fineza, amor es, y el amor más entendido: que más firme será contra el olvido si en dos basas estriba su firmeza.

Niñas, si me cortáis pieza por pieza, hay para entrambas; $y$, pues siempre ha sido señal de sujeción darse a partido ${ }^{63}$, partidme, y no quebrarse la cabeza.

Amor y odio ya en el campo estrecho del corazón batallas han tenido, juntos en él, aunque entre sí distantes;

61 Cancionero sevillano de Nueva York, ed. cit., núm. 483.

62 Como dice la copla mexicana: "Ya tengo visto el nopal / donde he de cortar la tuna: / como soy hombre formal, / no me gusta tener de a una; / me gusta tener de a dos, / por si se me enoja alguna".

63 "Darse uno a partido", según el Diccionario, es “ceder de un empeño u opinión’; pero Solís juega del vocablo. 
pues si a un tiempo tal vez dentro del pecho dos afectos contrarios han cabido, ¿por qué no han de caber dos semejantes?

Movido de argumentos tan bastantes, medio partirme entre vosotras quiero dándome a cada una por entero, de suerte que por mí pueda decirse: irse y quedarse, y con quedar partirse 64 .

El argumento de los tercetos -si caben en el pecho dos afectos tan contrarios como amor y odio (el Odi et amo catuliano), ¿por qué no han de caber dos afectos hermanos (amor y amor)? - se parece al de Quevedo en el soneto "Si de cosas diversas la memoria..." ("Filosofía con que intenta probar que a un mismo tiempo puede un sujeto amar a dos"): si las potencias del alma, memoria, entendimiento y voluntad, valen para infinidad de objetos, y si el Amor es ya no potencia, sino "omnipotencia”, ¿por qué no podría dar cabida a más de una amada? En cuanto al sofisma de "darse entero a pesar de darse partido", parece tener el apoyo (subterráneo) de los sesudos teólogos que demuestran que Cristo está entero hasta en la menor partícula de una hostia. (El verso final es uno de los muchísimos testimonios de la fama que tuvo el "Ir y quedarse..." de Lope de Vega.)

Lope de Vega fue el máximo explotador del Hanc amo de Ausonio, por la sencilla razón de que el amar y el aborrecer fueron durante muchos años (no sólo los de la mocedad) experiencias muy suyas. Vida convertida en literatura (Literarisierung des Lebens, como dijo Karl Vossler), en fuerte contraste con Góngora, tan parco y tan reticente. Nada hay en los romances gongorinos que se parezca a los de Belardo y sus relaciones con Filis y con Belisa. En las Rimas, publicadas por primera vez en 1602, abundan los sonetos "autobiográficos". Así el núm. 168:

64 Antonio de Solís, Obras, ms. 3667 de la B.N.M., f. 34v ("Un amante se halló empeñado en dezir que quería a dos damas en un mismo tiempo y las ymbió este soneto"). También en la edición póstuma de las Varias poesías de Solís, Madrid, 1692, p. 22. 
Si verse aborrecido el que era amado es de amor la postrera desventura, ¿que espera en vos, señora, qué procura el que cayó de tan dichoso estado?

En vano enciendo vuestro pecho helado, pues lo que agora con violencia dura ya no es amor, es natural blandura con tibio gusto de un amor forzado.

Cuando vos me seguisteis iba huyendo; huís agora cuando yo os sigo. Si es amor, yo le tengo y no le entiendo: ya huyo, como esclavo del castigo. Guardáos, que ya me voy, y al fin partiendo, no sé qué haré de vos, pues vais conmigo ${ }^{65}$.

Lope, en resumidas cuentas, no entiende por qué se obstina en seguir a esa "señora" que antes lo quiso y ahora lo aborrece, seguramente con razón (el verso final se parece a "ir y quedarse y con quedar partirse"), pues reconoce que es un amor "forzado", mera ceniza, "tibio" recuerdo del que antes tuvo, sin ninguna fuerza de convicción; pero lo único propiamente ausoniano es el primer terceto ('huí cuando me seguías, huyes cuando te sigo'). La reminiscencia de Ausonio es más clara en una serie de sonetos recitados por personajes suyos en varias comedias escritas a lo largo de los años sucesivos. Nada le era más fácil que aprovechar cualquier situación teatral de amor y desamor para lucirse: sus propios recuerdos le hacían poner "sentimiento" en sus versos. Además, podía halagar el gusto de los conocedores mostrando familiaridad con un poeta latino de la antigüedad. El primero de la serie es éste:

Amo a quien me aborrece, aborreciendo a quien me quiere; adoro a mi enemigo; huyo de quien me va siguiendo, y sigo la misma sombra que de mí va huyendo;

muero por quien por otro está muriendo, y a quien me da su vida, a muerte obligo; a quien me sigue con lealtad, persigo, y a quien jamás me paga estoy sirviendo.

Así por este mar de Amor navego; con hielo abraso, y nieve, en fin, me enciende; donde sigo mi error, la razón niego:

65 Lope DE VEGA, Obras poéticas, ed. J. M. Blecua, Barcelona, 1983, p. 123. 
que cuando Amor lo que es razón pretende, ya no es amor, que Amor es niño y ciego; cual ciego mira, y como niño entiende ${ }^{66}$.

El segundo es éste:

Amor, quien más de ti piensa que entiende, menos sabe de ti, porque ofendido tienes memoria, y pagas con olvido a quien servirte más leal pretende.

Amor ingrato, la verdad te ofende y estás a la mentira agradecido; precipitas el alma resistido, la fe te hiela y el desdén te enciende.

Quien más tiene de ti, menos adquiere; nadie verdad a tus engaños pida, ni menos que rigor, amado, espere.

Dé un medio Amor para pasar la vida, pues aborrezco a quien me adora y quiere, y quiero locamente a quien me olvida ${ }^{67}$.

Muy parecido al anterior es este otro:

Aborrecí querido, y olvidado quiero, por condición de Amor injusto: que la satisfacción causa disgusto y la sospecha enciende un pecho helado.

A quien me quiere olvido y, desamado, adorar un desdén tengo por justo: tal es la diferencia con que el gusto desprecia amado, y quiere despreciado.

Amor que los deseos satisface ya no es amor, sino amoroso empleo que quiere aquello que su gusto hace;

pues por tan claras experiencias veo que en la dificultad el amor nace, y en la facilidad muere el deseo ${ }^{68}$.

El último es, para mí, el mejor redondeado:

${ }^{66}$ Lo dice Federico en El halcón de Federico (Acad, t. 14, p. 446).

${ }^{67}$ Lo recita Ramiro en El galán de la Membrilla (Acad, t. 9, p. 95).

68 Lo dice Don Juan en El príncipe perfecto, Primera parte, acto III (Acad, t. 10 , p. 479). 
Amaba Filis a quien no la amaba, y a quien la amaba, ingrata aborrecía; hablaba a quien jamás la respondía, sin responder jamás a quien la hablaba.

Seguía a quien huyendo la dejaba, dejaba a quien amando la seguía; por quien la despreciaba se perdía, y al perdido por ella despreciaba.

Concierta, Amor, si ya posible fuere, desigualdad que tu poder infama: muera quien vive, y vivirá quien muere.

Da hielo a hielo, Amor, y llama a llama, por que pueda querer a quien la quiere y pueda aborrecer a quien desama ${ }^{69}$.

El camino recorrido por la poesía de lengua española entre Lope de Vega y los decenios finales del siglo XVII puede ejemplificarse muy bien con el siguiente soneto del portugués Jerónimo Bahia, publicado en la gran antología intitulada A Fénix renascida:

Duro a ternezas, tierno a disfavores, sordo a mil quejas, y a mil rayos ciego, amo desdenes, desdeñando amores; ruego el desprecio, despreciando el ruego.

Es Filis hielos, Cloris es ardores; mas dando a Filis lo que a Cloris niego, cogiendo espinas y dejando flores, fuego a la nieve soy, soy nieve al fuego.

Vuelto en escarcha, en llama convertido, Etna que en el incendio está nevado, Etna soy que en la nieve está encendido.

Cese, Amor, mi descuido o mi cuidado: o no olvide ya más, siendo querido, o no quiera ya más, siendo olvidado.

Este soneto es una obra maestra de barroquismo. Vale la pena leerlo despacio, admirando verso a verso las rigurosas sime-

${ }^{69}$ Lo dice Doña Ana en La moza de cántaro (AcadN, t. 13, p. 659). -Según S. Griswold Morley y Courtney Bruerton, Cronología de las comedias de Lope de Vega, Madrid, 1968, las fechas son éstas: El halcón de Federico, 1601/1605; El galán de la Membrilla, 1615; El príncipe perfecto, quizá 1616; La moza de cántaro, $1618 / 1625$. 
trías, casi matemáticas, y los artificiosísimos contrastes. Es como "otra vuelta de tuerca" a los sonetos de Lope. De éstos parecería venir la insistente antítesis de la nieve y el fuego (El halcón de Federico: "con hielo enciendo, y nieve, en fin, me abrasa"; La moza de cántaro: "da hielo a hielo, Amor, y llama a llama"). Pero bien pudo Bahia escribir el suyo sin conocer los de Lope: le bastaban la idea generadora de Ausonio y la enorme "ciencia poética" acumulada en su propio siglo, la retórica gigantesca creada por varias generaciones. Estos catorce versos bien pueden tomarse como representativos de toda una vasta tendencia de la poesía barroca hispánica ${ }^{70}$.

Estimulado quizá por el tour de force de Bahia, el brasileño Gregório de Matos (1633-1696) se propuso sacarle jugo al Hanc amo con otro género de complicación, discurriendo sobre aspectos que se quiebran de sutiles y dedicando al asunto nada menos que seis sonetos, tres en labios del propio poeta, dirigidos a Floralba, y los otros tres en labios de Floralba. Dice el primero:

Já desprezei, sou hoje desprezado; despojo sou de quem trïunfo hei sido, e agora, nos desdéns de aborrecido, desconfio as ufanias de adorado.

$\mathrm{O}$ amor me incita a um perpétuo agrado;

o decoro me obriga a um justo olvido, e não sei, no que emprendo e no que lido, se trïunfe o respeito, se o cuidado.

Porém vença o mais forte sentimento: perca o brio maior autoridade, que é menos o ludíbrio que o tormento.

Quem quer, só do querer faça vaidade, que quem logra em amor entendimento, não tem outro capricho que a vontade.

${ }^{70}$ Los cinco tomos de A Fénix renascida, ou Obras poéticas dos melhores engenhos portuguezes, se imprimieron entre 1716 y 1728 y se reeditaron en 1746 . Contienen sobre todo composiciones escritas en los últimos decenios del siglo xvir, muchas de ellas por Jerónimo Bahia. Abundan en la Fénix las poesías en castellano. Tal vez esta circunstancia (unida al muy generalizado desprecio por el "barroco degenerado") ha sido causa del olvido en que la crítica portuguesa tiene esta época. En el Dicionário das literaturas portuguesa, galega e brasileira dirigido por Jacinto do Prado Coelho (Porto, 1960) no hay artículo dedicado a Bahia. Según Nuno Catarino Cardoso, Sonetistas portugueses e luso-brasileiros, Lisboa, 1918, p. 35, era monje benedictino y murió en 1688 . 
Intentaré una explicación. En un primer tiempo Floralba amaba al poeta y éste no le hacía caso, y ahora se ve desdeñado por ella: de triunfador ha pasado a despojo; al orgullo de haber sido amado ha sucedido la humillación actual; pero lo que ha conseguido Floralba con su desvío es picar al poeta, que ahora la ama; el amor lo impulsa a ganársela, pero el decoro (la autoestima, el sentido de dignidad) se lo impide, de manera que en cuanto emprende y en cuanto "lidia" no sabe qué es lo que debe predominar, si el respeto (el decoro) o el cuidado (el amor). Pero el sentimiento (la pasión amorosa) es más fuerte que la autoridad (la honra, el respeto social); y el ludibrio (las burlas a que se expone por no haberse mantenido en sus trece) no es tan grave como el tormento (de la insatisfacción). Ufánese el amante de amar sin esperanza: ésa es la mayor fineza, y no una baladí victoria $^{71}$.

En el segundo soneto, hecho no sólo por los mismos consonantes, sino con las mismas palabras-rimas, el poeta se decide por lo contrario. Bastará comparar su final con el del otro:

Manter respeito é honra, e não vaidade, e a honra tem lugar no entendimiento, que é potência mais nobre que a vontade.

No quiere el poeta que se burlen de él, y esto no es vanidad, sino honra, y la honra reside en el entendimiento, y el entendimiento es una potencia del alma más fuerte que la voluntad.

En el tercer soneto, hecho también con las mismas palabrasrimas, el poeta hace un capcioso silogismo para demostrarse a sí mismo que puede seguir amando sin perder el decoro (que puede callarles la boca a quienes lo motejen de debilucho).

Vienen en seguida los tres sonetos puestos en boca de Floralba. Los tres están hechos con las mismas palabras-rimas y los tres dicen cosas distintas. Copio sólo el primero:

Querida amei, prosigo desdenhada, e de amor e decoro combatida; me dá glória e tormento uma ferida, sentindo o golpe, festejando a espada.

71 Ojalá haya lectores más atentos y más pacientes que yo, que logren una glosa o paráfrasis más atinada que la mía. 
Mas se do amor o empenho só me agrada, não olho ao que o respeito me convida, pois se em saber amar esgoto a vida, em a honra perder não perco nada.

Se o querer no desprezo é não ter brio, fora o deixar de amar não ter vontade, e nada é mais em nós que o alvedrio.

Cárcere a honra, o gosto imunidade: logo fora em mim cego desvario trocar pela prisão a liberdade.

Es un soneto menos enredoso que el primero de la otra serie. En el pecho de Floralba combaten el amor y el decoro (la honra, el respeto), pero el decoro es cárcel y el amor es libertad. ¡Que triunfe, pues, el amor! Los otros dos sonetos de Floralba siguen los carriles trazados por los de la voz masculina. Es la locura72.

\section{VII}

Lo que hace notable a Gregório de Matos no es tanto su desaforado barroquismo (compartido con sus contemporáneos), sino el hecho de que haya tomado en cuenta a Floralba y le haya dado, para expresar su punto de vista, el mismo espacio que se dio a sí mismo. En la mayor parte de los textos que hemos visto no hay tal cosa. La mujer es un ser débil y voluble; no es dueña de sí misma; su opinión y su sentir no cuentan. La mujer debe, en la práctica, tolerar las infidelidades de su dueño y señor, pero no viceversa. Etc., etc. Recordemos la historia que cuenta Sancho Panza (Don Quijote, I, 20): Lope Ruiz, enamorado de la Torralba, vino a aborrecerla por "cierta cantidad de celillos que ella le dio, tales, que pasaban de la raya y llegaban a lo vedado"; y entonces, picada por el desdén de Lope Ruiz, la Torralba se puso a quererlo de veras. En este punto Don Quijote no puede menos de interrumpir a Sancho para intercalar espontánea y mecánicamente un pequeño comentario: "Ésa es

72 GregóRio de Matos, Obra poética completa, ed. James Amado, Rio de Janeiro-São Paulo, 1999, tomo 2, pp. 1202-1205. Hay que añadir que los seis sonetos van precedidos de una serie de romances y décimas del poeta a Floralba y las respuestas de ella, siempre con las mismas palabras-rimas. (Por cierto que Matos poetizó también en castellano.) 
natural condición de mujeres, desdeñar a quien las quiere y amar a quien las aborrece". Es lo que piensan todos los contemporáneos de Cervantes, y Cervantes mismo. A esa idea los había llevado su cultura, procedente de los clásicos (v.gr. Aristóteles) y de la Biblia (v.gr. el Eclesiastés y san Pablo) ${ }^{73}$.

Salta a la vista la contradicción que hay entre el deprimente comentario de Don Quijote y la historia que Cervantes ha contado seis capítulos antes, con el díptico formado por la larga "canción desesperada" de Grisóstomo y la igualmente larga defensa de Marcela, a quien todo el mundo ve como causante del suicidio del desamado pastor: "No alcanzo que, por razón de ser amado, esté obligado lo que es amado a amar a quien le ama... El que me llama fiera y basilisco, déjeme como cosa perjudicial y mala; el que me llama ingrata, no me sirva; el que desconocida, no me conozca; quien cruel, no me siga; que esta fiera, este basilisco, esta ingrata, esta cruel y esta desconocida ni los buscará, servirá, conocerá ni seguirá de ninguna manera". Marcela reivindica su voluntad, sus sentimientos y su libertad: se niega a ser un juguete o un títere, quiere ser una persona entera y autónoma. Si Cervantes se extremó en la elaboración retórica de este discurso, fue evidentemente porque sentía que Marcela tenía razón. Y es natural que Don Quijote, "puesta la mano en el puño de su espada", sentencie enfáticamente: "Ella ha mostrado con claras y suficientes razones la poca o ninguna culpa que ha tenido en la muerte de Grisóstomo".

Creo que Américo Castro explica bien esta contradicción. Después de citar buen número de pasajes misóginos, a partir de la Galatea ("Ha dado la palabra de ser esposa de Antandro, y agora, por cumplir con la condición mudable de mujer, la ha negado"), dice: "Se impone la conclusión de que Cervantes tenía no muy buena opinión de la mujer; para lograr tipos femeninos deliciosos y encantadores [y ejemplares, como Marcela], tenía que forjarlos mediante el arte". La visión de la vida era doble en Cervantes: a lo "particular prosaico" sobreponía lo "uni-

73 Francisco Rodríguez Marín, en nota a este pasaje del Quijote, cita a Terencio ("novi ingenium mulierum: / nolunt ubi velis; ubi nolis, cupiunt ultro", Eunuco, 812-813), a Ovidio ("Quod refugit, multae cupiunt; odere, quod instat", Ars amandi, I, 717), a Carvajales, poeta de fines del siglo xv ("que siguen a quien las fuye / e fuyen de quien las sigue"), a un poeta del Romancero general ("aborrecen lo que alcanzan, / mueren por lo que se aleja”), y dice que hay "centenares de ecos de estas voces". 
versal poético"74. No de otra manera Calderón, que hace decir a Julia: "Tales somos las mujeres, / ...que, queridas, despreciamos, / y aborrecidas, queremos" (supra, pp. 113-114), puede también crear en Amado y aborrecido dos personajes femeninos que se mantienen firmes a lo largo de la pieza: Aminta, constante en su amor, e Irene, constante en su aborrecimiento. Los volubles y tornadizos son Dante y Lidoro.

La primera mujer que escudriñó por sí misma y expuso con su propia voz poética el conflicto ausoniano del dýseros $-\mathrm{o}$, dicho de otro modo, quien por primera vez escribió Hunc amo en vez de Hanc amo- fue sor Juana Inés de la Cruz. Es verdad que, antes de ella, una mano femenina había escrito este notable soneto:

Ni sé si muero ni si tengo vida; ni estoy en mí, ni fuera puedo hallarme; ni en tanto olvido cuido de buscarme, que estoy de pena y de dolor vestida;

dame pesar el verme aborrecida, y si me quieren, doy en disgustarme; ninguna cosa puede contentarme; todo me enfada y deja desabrida;

ni aborrezco, ni quiero, ni desamo; ni desamo, ni quiero, ni aborrezco; ni vivo confiada ni celosa;

lo que desprecio a un tiempo adoro y amo. Vario portento en condición parezco, pues que me cansa toda humana cosa.

Pero Leonor de la Cueva y Silva, su autora ${ }^{75}$, no está en la línea de Ausonio. La mujer que habla en el soneto sufre si la aborrecen, pero sufre exactamente igual si la aman; es una infeliz absoluta y trágica, tan rodeada "de pena y de dolor", que ni siquiera procura "buscarse" a sí misma. Los verbos amary adorar aparecen sólo en el terceto final, pero no aplicados a alguien, sino a algo: lo que la "enamora" es su extraño talante de aborrecer "toda humana cosa". Es un Timón de Atenas con faldas.

Sor Juana sí que está en la línea de Ausonio: "Amo a quien me aborrece y aborrezco a quien me ama”. Los lectores que ha-

74 Américo Castro, El pensamiento de Cervantes, Madrid, 1925, pp. 126-127.

75 Soneto incluido por Ana Navarro en su Antología poética de escritoras de los siglos XVI y XVII, Madrid, 1989, p. 189. (Leonor de la Cueva murió en 1650.) 
yan llegado a esta página tendrán la posibilidad de leer los sonetos sorjuaninos de las "encontradas correspondencias" más o menos como los leyeron los contemporáneos de la monja, pues conocen más o menos lo mismo que ellos conocían, o sea los "antecedentes" de esos sonetos, su pedigree. No es que sor Juana haya leído todos los textos que he recogido (es imposible, por ejemplo, que conociera a Gregório de Matos), pero sí había leído otros (por ejemplo los de Lope de Vega) y quizá algunos más que a mí se me habrán escapado. El tema, tan provocador, había engendrado un corpus, una "tradición" literaria. Y justamente el trasfondo de la tradición hace destacar la originalidad y el ingenio de la monja poetisa, la seriedad de sus cavilaciones, su afán de superar a los predecesores. Leamos los sonetos en el orden que tienen en la Inundación castálida:

Resuelve la questión de cuál sea pesar más molesto en encontradas correspondencias: amar o aborrecer.

Que no me quiera Fabio al verse amado, es dolor sin igual en mi sentido; mas que me quiera Silvio, aborrecido, es menor mal, mas no menor enfado.

¿Qué sufrimiento no estará cansado si siempre le resuenan al oído, tras la vana arrogancia de un querido, el cansado gemir de un desdichado?

Si de Silvio me cansa el rendimiento, a Fabio canso con estar rendida; si de éste busco el agradecimiento,

a mí me busca el otro agradecida. Por activa y pasiva es mi tormento, pues padezco en querer y en ser querida.

II

Prosigue el mismo asunto, y determina que prevalezca la razón contra el gusto.

$\mathrm{Al}$ que ingrato me deja, busco amante; al que amante me sigue, dejo ingrata; 
constante adoro a quien mi amor maltrata; maltrato a quien mi amor busca constante; al que trato de amor, hallo diamante, y soy diamante al que de amor me trata; triunfante quiero ver al que me mata, y mato a quien me quiere ver triunfante.

$\mathrm{Si}$ a éste pago, padece mi deseo; si ruego a aquél, mi pundonor enojo. De entrambos modos infeliz me veo; pero yo por mejor partido escojo de quien no quiero, ser violento empleo, que de quien no me quiere, vil despojo.

\section{III}

Continúa el asunto, y aún le expresa con más viva elegancia.

Feliciano me adora, y le aborrezco; Lisardo me aborrece, y yo le adoro; por quien no me apetece, ingrato, lloro, $\mathrm{y}$ al que me llora, tierno, no apetezco;

a quien más me desdora, el alma ofrezco; a quien me ofrece víctimas, desdoro; desprecio al que enriquece mi decoro, y al que le hace desprecios enriquezco; si con mi ofensa al uno reconvengo, me reconviene el otro a mí, ofendido. Y a padecer de todos modos vengo, pues ambos atormentan mi sentido: aquéste con pedir lo que no tengo, y aquél con no tener lo que le pido.

El "tema" ausoniano es como el cantus firmus de tres "variaciones": I, Fabio y Silvio; II, el Ingrato y el Amante; III, Lisardo y Feliciano. Al igual que las variaciones (o "diferencias") musicales, cada soneto es una entidad autónoma. No son como los de Gregório de Matos, dispuestos en una verdadera secuencia: 'elijo A' > 'mejor elijo B' > 'prefiero elegir A y B a la vez'76. Alfonso Méndez Plancarte intercambió el orden de los sonetos II y III, seguramente porque el II termina con una solución del 119.

${ }^{76}$ Recuérdense las tres décimas de Antonio de Mendoza, supra, pp. 118 - 
conflicto: la mujer que habla escoge ser "violento empleo" de aquel que la ama (prefiere ceder, violentándose a sí misma, a las solicitaciones de ese amante) en vez de convertirse en "vil despojo" de aquel que no la ama (pues ofrecérsele, entregársele, sería rebajarse vilmente). Pero yo creo que hay que respetar el orden en que los sonetos se imprimieron. El soneto II no es una conclusión, sino una de las tres variaciones autónomas.

La variedad del vocabulario del amor y el desamor pone muy de manifiesto esta autonomía. El único vocablo que aparece en los tres sonetos es padecer, en el I y el II hay amar, querery buscar, en el I y el III, sentiry aborrecer, en el II y el III, ingratitudy adorar. Pero, salvo estos ocho casos, cada soneto tiene sus conceptos propios, su "tonalidad léxica" distintiva:

I. agradecer, rendirse, desdeñar, gemir, sufrir, mal, dolor, tormento, enfado, cansancio, vanidad, arrogancia;

II: rogar, desear, tratar de amor, escoger, pagar, triunfar, dejar, enojar, maltratar, matar, empleo, constancia, diamante ('dureza'), despojo, infelicidad, pundonor, vileza;

III. apetecer, pedir, llorar, ofrecer el alma, ofrecervictimas, enriquecer, despreciar, ofender, reconvenir, desdorar, atormentar, termura, decoro.

Es enorme la diferencia entre estos sonetos y los de Gregório de Matos, que no sólo repite los mismos conceptos a lo largo de cada uno de los sonetos, sino que termina los catorce versos de cada uno con unas mismas palabras. No hay duda de que sor Juana puso especial esmero en no repetirse ${ }^{77}$.

Para mayor claridad, en los análisis que siguen voy a llamar "Celia", y no "sor Juana", a la mujer que habla en las poesías ${ }^{78}$. Y, como los nombres de "Fabio" y "Silvio" reaparecen en otros lugares, los emplearé siempre (aunque de hecho se llamen Lisardo y Feliciano, o aunque no tengan nombre, como es el caso del soneto II). Ni Celia, ni Fabio, ni Silvio son de una pieza, sino que experimentan ciertas transformaciones, como para ma-

77 Caso distinto es el del dístico sonetil "Dices que yo te olvido, Celio, y mientes..." y "Dices que no te acuerdas, Clori, y mientes..." (ed. Méndez Plancarte, núms. 180-181). Clori le dice a Celio: 'Te he borrado completamente de mi memoria'; y Celio la refuta: 'Lo que me dices es clara señal de que sigues acordándote de mí'. Aquí el segundo soneto tiene, adrede, las mismas palabras-rimas que el primero. (En las páginas que siguen pongo el número que Méndez Plancarte asigna a cada poesía.)

78 "Miró Celia una rosa...", comienza un soneto famoso; pero es claro que quien miró esa rosa (y quien pensó algo muy atrevido acerca de la hermosura) fue sor Juana. "Celia” es su yo poético. 
tizar o flexibilizar las encontradas correspondencias. Así, en el romance "Supuesto, discurso mío..." (núm. 4), Silvio no es un ser "aborrecido", como en el soneto I, sino un hombre dotado de buenas prendas, y además muy enamorado, de tal manera que el "mundo" entero le aconseja a Celia que lo prefiera a Fabio, igualmente dotado de buenas prendas, pero que no la ama. El sentido común y los usos sociales son una verdadera "razón de estado", que está por encima de las egoístas consideraciones del deseo. Así lo reconoce Celia:

Manda la razón de estado que, atendiendo a obligaciones, las partes de Fabio olvide, las prendas de Silvio adore.

Esa maquiavélica razón de estado es la que acepta la Celia del soneto II: prefiere entregarse a Silvio, que la ama, y no a Fabio, que la trataría como guiñapo. Pero en el resto del romance reflexiona Celia largamente sobre ese Silvio que la ama simplemente porque está siguiendo su inclinación (mientras que ella emplea todas sus potencias en conquistar a Fabio):

¿Qué hace en adorarme Silvio, cuando más fino blasone?

¿Quererme es más que seguir

de su inclinación el norte?...

¿Qué víctimas sacrifica, qué incienso en mis aras pone...?79

Celia se horroriza de sólo pensar lo que sería su vida si se entregara a Silvio: tendría que "fingir halago" todo el tiempo, y todo el tiempo "mentir rigores" al pensar en el adorado Fabio:

¿Cómo podré yo mostrarme, entre estas contradicciones, a quien no quiero, de cera; a quien adoro, de bronce?

79 Cf. las décimas "Al amor, cualquier curioso..." (núm. 104), donde hay dos amores: uno que nace de elección, o sea de la voluntad, y otro que nace del "influjo imperioso" de "la Estrella"; y la autora, como dice el epígrafe, "defiende que amar por elección del arbitrio es [lo único] digno de racional correspondencia”. Véase la nota de Méndez Plancarte, que cita varios textos clásicos acerca de estos dos amores. 
En la última cuarteta concluye Celia que no ha valido la pena apuntalar con razones lo que es obvio:

Y en fin, cuando en mi favor

no hubiera tantas razones, mi voluntad es de Fabio:

¡Silvio y el mundo perdonen!

Las redondillas "Dos dudas en que escoger..." (núm. 85) parecen un complemento del romance que acabo de comentar. Ahora, en vez de analizar para sí misma su relación con Silvio, Celia se dirige a él. Imposible acceder a sus súplicas; si lo hiciera, sería desdichada. A Silvio, naturalmente, le parecerá injusto ver pagado su gran amor en moneda de dureza y aborrecimiento:
...y aun irracional parece
este rigor, pues se infiere:
si aborrezco a quien me quiere,
¿qué haré con quien me aborrece?80

No, no se trata de rigor ni de aborrecimiento. Celia no está enamorada de Silvio, eso es todo; pero siempre lo tratará con afecto,

\author{
y así quedo, en mi entender, \\ esta vez, bien con los dos: \\ con agradecer, con vos; \\ conmigo, con no querer,
}

y termina con una reflexión filosófica: como la felicidad perfecta (el "gusto cumplido") no es cosa de este mundo, no queda sino aceptar resignadamente los hechos.

En otras redondillas muy cortesanas ("Silvio, tu opinión va errada...”, núm. 86) le replica Celia a Silvio, que mañosamente había dicho que las mujeres enamoradas se ponen más bonitas. En cambio, la décima "Tenazmente porfiado / intentas, Silvio..." (núm. 118) es un franco regaño: 'La excusa que me das por tu mala acción es peor que tu culpa'. Esta décima nos permite asomarnos al proceso de "elaboración" de las dos figuras

80 Esta idea parece tomada de Ovidio, Heroida XXI, 59: "Si laedis quod amas, hostem sapienter amabis". 
paradigmáticas. De primer intento no iba dirigida a Silvio, sino a Fabio, pero al mandar a Madrid los originales de la Inundación castálida, cuando la polaridad estaba ya consumada, vio sor Juana que el tirón de orejas le cuadraba a Silvio mejor que a Fabio $^{81}$. En efecto, en la Inundación castálida están, uno al lado del otro, dos tremendos sonetos dirigidos a Silvio ("Cuando mi error y tu vileza veo..." y "Silvio, yo te aborrezco, y aun condeno...", núms. 170 y 171), en los cuales Silvio no es simplemente alguien a quien Celia no ama, sino un ser por quien ella siente un odio que llega al paroxismo. Y es que en ellos revela Celia algo que falta en las demás poesías relativas a Silvio: ¡ella, en un tiempo, le tuvo gran amor a ese monstruo! Recordaré sólo el final de estos sonetos admirables: 'En pena de haberte querido, hago pública confesión de mi delito'; 'El solo recordarte me produce asco, pero acepto este asco: es el castigo que me he merecido'.

No podía ser mayor el contraste entre estos dos sonetos, apoteosis del odio, y el "Detente, sombra de mi bien esquivo..." (núm. 165), apoteosis del amor, un amor que persiste, siempre ardiente. Se trata del mismo Fabio de los tres sonetos de "encontradas correspondencias", amado pero esquivo. He aquí que de pronto se presenta este Fabio ante Celia, y Celia corre a estrecharlo entre sus brazos, pero él se le escabulle, tal como se le escabulle a Ulises la sombra de su madre. Porque Fabio es una sombra, una imagen, una ilusión bella, una dulce ficción. Ha sido un sueño, fugaz como todos los sueños eróticos. Pero no importa: tener siempre a Fabio en la fantasía será como prolongar por siempre el instante dichoso.

El soneto "Detente, sombra..." es seguramente posterior a los sonetos dirigidos a Silvio, pues no figura en la Inundación castálida. Aquí, al único soneto a Fabio ("Fabio, en el ser de todos adoradas...", núm. 169) es muy discreto: 'A las mujeres les encanta tener muchos amantes; yo, en cambio, no quiero tener sino uno: aquel a quien mi corazón ha elegido'. No le dice 'Ése eres tú, pero tampoco hay alusión a "esquivez". Y lo que hay en otras poesías dirigidas a Fabio -romance "Si el desamor o el enojo...", núm. 5; romancillos "Sabrás, querido Fabio..." y "Si

${ }^{81}$ Es lo que se deduce de una copia de versos de sor Juana hecha antes de que se imprimiera la Inundación castálida: manuscrito de la biblioteca de Antonio Rodríguez-Moñino, editado por William C. BRYant en ALM, 4 (1964), pp. 277-285. 
acaso, Fabio mío...", núms. 75 y 76- no es sino amor desbordante, sin mención alguna de falta de correspondencia. Sólo en la glosa de "Si de mis mayores gustos..." (núm. 140) hay una queja por los "desdenes", pero Celia no culpa a Fabio, sino a su funesta suerte (su "estrella").

Las liras "Amado dueño mío...", "Pues estoy condenada..." y "A estos peñascos rudos..." (núms. 211-213) tienen un lugar aparte. Desarrollan tres accidentes dolorosísimos de una relación amorosa: la ausencia, los celos y la muerte, y en lenguaje intensamente lírico proclaman la fuerza incontrastable del amor.

Francisco de las Heras, secretario de la condesa de Paredes y editor de la Inundación castálida, quiso evidentemente que los lectores comprobaran lo antes posible los quilates del volumen, y por eso escogió para el comienzo las composiciones de éxito garantizado (por así decir): las más originales, las más capaces de seducirlos. A continuación del soneto-dedicatoria colocó el del retrato ("Este que ves, engaño colorido...", con su impresionante verso final, homenaje a Góngora), e inmediatamente después el tríptico de las "encontradas correspondencias", variaciones sobre un tema de todos conocido, pero ahora dotado de nueva vida, pues por primera vez una mujer tomaba la idea ausoniana planteándose a sí misma el arduo problema de las inclinaciones eróticas.

En 1689, cuando se imprimió la Inundación, hacía siete años que sor Juana se había liberado del austero tutelaje del padre Antonio Núñez, su director espiritual. No hace falta ningún esfuerzo de la imaginación para comprender el escándalo del jesuita ante los versos "mundanos" de esa mujer a quien él había querido convertir en una monja santa, muerta al mundo. Y, desde luego, no sería Núñez el único escandalizado. Bien que lo sabía fray Luis Tineo, eclesiástico eminente y amigo de las buenas letras, a quien -seguramente por "cabildeos" de la poderosa condesa de Paredes- se encomendó la reglamentaria "Aprobación" del libro. Tineo aprovechó sagazmente la ocasión para escudar a sor Juana contra las censuras de los mojigatos. Versos como los que aquí se le ofrecen al lector -dice- "no son sino recreación honestísima y empleos decentísimos del religioso más ajustado, porque ya se ve que es disparate pensar que ha de estar siempre tirada la cuerda del arco". También Francisco de las Heras vio la necesidad de salvar el "óbice" de la mundanidad. En su prólogo llama la atención sobre el soneto 
en que dice sor Juana que cultivar las letras es mejor que "consumir la vida en vanidades", y lo comenta así: "Con esta verdad elegante enseña que es mejor emplear lo que sobra del tiempo en estos discursos salados al oído, maestros al entendimiento y sin tropiezos a la honestidad, que empeorar los ratos del ocio, o en vanidades de más leves efectos (que le desperdician) o en cuidados funestos (que le hacen más delincuente)" 82 . Y el padre Diego Calleja, amigo epistolar y biógrafo de sor Juana, dice en su Elegía funeral:

Jamás habréis leído con más gusto amores que ella escribe sin amores, amores que a lo honesto no dan susto.

Pero cuando, tras el largo eclipse que se inició hacia 1740, volvió sor Juana a tener unos pocos lectores en el siglo XIX, la crítica literaria, nutrida de romanticismo, no podía concebir que un buen poema de amores hubiera sido escrito "sin amores": la poesía de sor Juana delataba a una mujer enamorada que expresaba auténticas vivencias. Ya en 1819 cierto José Bocous decía en el artículo "LACRUz (JEANNE-INÈs DE LA)" de la gran Biographie universelle publicada en París: "Aspiraron a su mano muchos jóvenes de las primeras familias de Méjico, entre los cuales, como era natural, dio Inés la preferencia a uno a quien amaba, y tuvo la desgracia de perderle cuando iba a unirse a él con lazo indisoluble. Desde entonces sólo pensó ya en el retiro". Fue esto, más o menos, lo que se siguió - y a veces se siguediciendo ${ }^{83}$.

Dando un paso más, algún crítico liberal de tiempos de Juárez pudo fácilmente concluir que los versos de amor de sor Juana, y concretamente los de las "encontradas correspondencias",

82 Es lo que sor Juana había dicho en su Carta de 1682 al padre Núñez: “¿Por qué ha de ser malo que [dedique a la literatura] el rato que yo había de estar en una reja hablando disparates, o en una celda mormurando cuanto pasa fuera y dentro de casa, o peleando con otra, o riñendo a la triste sirviente, o vagando por todo el mundo con el pensamiento", como hacen tantas monjas? (No es improbable que sor Juana le haya mostrado esta carta a su amiga la condesa, y que también el secretario Las Heras la haya leído.)

${ }^{83}$ El texto de Bocous se imprimió en francés. Cito por la traducción española publicada en 1831 en el Diccionario histórico o Biografía universal compendiada. Sobre toda esta cuestión puede verse A. Alatorre y Martha Lilia TEnorio, "Una enfermedad contagiosa: los fantaseos sobre sor Juana", NRFH, 46 (1998), 105-121. 
son señal de que el "retiro" conventual distó mucho de ser un alivio; fue más bien una prolongada frustración; ella, en su encierro, no hacía sino añorar la libertad. (En la visión liberal-masónica de la segunda mitad del siglo XIx, los conventos de monjas eran cárceles inhumanas que debían suprimirse, como lo intentaron en efecto las Leyes de Reforma.) A monseñor Ignacio Montes de Oca, obispo de San Luis Potosí ("Ipandro Acaico" entre los Árcades de Roma) no le costó trabajo demostrar que la monja no hizo más que continuar un juego literario que se remontaba a la Antología griega y a Ausonio:

[Sor Juana] admira en dos o tres autores griegos y latinos la gracia con que pintan una cadena de amores no correspondidos; ve que revistiendo esos antiguos epigramas con el traje español y adornándolos con unos cuantos conceptos al estilo de Góngora, resultarán hermosas piezas, y hace que broten de su pluma tres bellos, aunque cultos, sonetos, de que se ha apoderado la censura moderna. "iVed - dice - una prueba de que el corazón de la monja estaba atormentado por tenaz y mal correspondida pasión! ¡Ved una prueba del estado violento en que se hallaba la religiosa, atada por vínculos que anhelaba romper!"84

Sin embargo, hasta los críticos católicos siguieron viendo los sonetos ausonianos como expresión de "vivencias" humanas. Menéndez Pelayo, por ejemplo, dice a propósito del soneto II ("Al que ingrato me deja..."): "El arranque de alma de la monja mejicana vale infinitamente más que el frío, aunque ingenioso, concepto de Ausonio" 85 .

Méndez Plancarte, en cambio, donde siente "más aire de emoción autobiográfica" es en el soneto I ("Que no me quiera Fabio...”). Y Alberto G. Salceda encontró tan autobiográficos los tres sonetos, que a base de ellos forjó una novelita ${ }^{86}$ : siendo "dama" de la marquesa de Mancera en el palacio virreinal, la jo-

84 Ignacio Montes de OCA, Obras pastorales y oratorias, México, 1882, tomo 2, pp. 83-89; citado por Francisco de LA MAZA, Sor Juana Inés de la Cruz ante la historia, México, 1980, p. 541. (Montes de Oca fue el humanista mexicano más conspicuo de sus tiempos: había estudiado en la Universidad de Oxford.)

85 Marcelino Menéndez Pelayo, Bibliografía hispano-latina clásica, Madrid, 1950, t. 1, p. 201.

86 Alberto G. Salceda, "Los amores de Juana Inés", en Novedades, 3, 10 y 17 de febrero de 1952. (En 1951, para conmemorar el tercer centenario del nacimiento de sor Juana, el periódico Novedades patrocinó un concurso de trabajos acerca de ella, y el de Salceda obtuvo el primer premio.) 
ven Juana Inés se enamoró perdidamente de un caballero que no quiso corresponderle, mientras que un fulano a quien ella odiaba con toda el alma la acosaba con sus requiebros; y tan explosiva fue la mezcla cuasi-química del enorme amor con el enorme odio, que la joven decidió encerrarse en un convento, no sin dejar constancia del conflicto en los tres sonetos. Éstos, pues, datarían del tiempo en que sor Juana no era monja aún ${ }^{87}$.

Veinte años antes de la novela de Salceda, ya habían tratado el tema los dos críticos mexicanos que pueden llamarse pioneros de los estudios sorjuaninos "serios": Ezequiel A. Chávez y Ermilo Abreu Gómez. El primero, lector de psicólogos franceses como Janet y Mendousse (Freud aún no contaba), había concluido, a base de un análisis de los poemas eróticos, que todos ellos (incluso "Esta tarde, mi bien, cuando te hablaba...") se escribieron antes de la entrada de Juana en el convento de las carmelitas, o bien en el período "cortesano" de un año y tres meses que medió entre su salida de ese convento y su entrada en el de San Jerónimo ${ }^{88}$. En particular, los sonetos de las "encontradas correspondencias" reflejan - dice- el típico "estado ambiguo" de la adolescencia, "período semi-amoroso", pues "las adolescentes no aman en realidad, sino juegan al amor", y en Juana este amor es "de tan poca raigambre, que le permite jugar donosamente" 89 . La respuesta de Abreu Gómez no se hizo esperar: la poesía amorosa de sor Juana - dice él- "fue redactada en función de recuerdo", dentro ya del convento; no es el "diario poético" de una adolescente; y existe, sobre todo, "un obstáculo invencible para admitir esta simultaneidad del senti-

$87 \mathrm{Al}$ comentar cosas "atrevidas" de sor Juana, los críticos católicos acuden, cuando pueden, al expediente de fecharlas en los años premonjiles. Así Méndez Plancarte, comentando los cinco sonetos burlescos escritos para "un doméstico solaz", dice: "Este «doméstico solaz» debe fecharse en Palacio, entre 1665 y 67 ", pues su sal es "demasiado gruesa, inferior al decoro" de la "exacta religiosa" que, según él, fue sor Juana. Y en nota a los versos 25-28 del romance "Traigo conmigo un cuidado..." (núm. 56) -"Yo me acuerdo... / que he querido en otro tiempo"-dice: "confesión, decisiva al parecer, de que tuvo en sus días de dama [de la virreina] un amor humano" (pero ese romance, escrito por sor Juana después de su "conversión" de 1693, se refiere a los años en que no fue monja ejemplar).

88 Curioso error cronológico de Chávez, pues Juana abandonó el muy austero convento de las carmelitas en noviembre de 1667, y en febrero de 1668 inició su noviciado en San Jerónimo.

${ }^{89}$ Ezequiel A. Chávez, Ensayo de psicología de sor Juana Inés de la Cruz, Barcelona, [1931], sobre todo pp. 39-55. 
miento amoroso de sor Juana y de su obra escrita: la cuestión de su técnica literaria"90. Lo cual, desde luego, no tiene vuelta de hoja. La carga conceptual -o sea la reflexión sobre el amor y el desamor- se traba tan finamente con la estructura en los sonetos de las "encontradas correspondencias", que éstos no pudieron brotar sino de una mente muy madura y muy nutrida de experiencia literaria ${ }^{91}$.

Sor Juana no se hizo monja por "vocación", sino por simple conveniencia, como claramente lo dicen ella y su biógrafo Calleja (dada "la total negación que tenía al matrimonio", no le quedó otro recurso). Pero en su alma hubo, durante los años conventuales, un persistente conflicto entre la "voluntad" y la "obligación": su voluntad la inclinaba irresistiblemente a las letras humanas, pero su obligación era vivir como digna esposa de Jesucrito. El mérito indiscutible de los dos libros de Ezequiel A. Chávez está en las luces que arrojan sobre esa pugna trabada en el alma de sor Juana ${ }^{92}$. De no haber sido por su profunda convicción de que los sonetos de las "encontradas correspondencias" son obra de una adolescente, bien hubiera podido llegar Chávez a una interpretación análoga a la que hizo Irving A. Leonard en 1955: la "esquivez" del amado Fabio representa la imposibilidad de satisfacer los íntimos anhelos de sor Juana, y el tenaz asedio del aborrecido Silvio es la ñoña rutina de las devociones y la vida de clausura ${ }^{93}$. Y en tal caso, lo que habría que

90 Ermilo Abreu Gómez, reseña del libro de Chávez en Contemporáneos, núms. 40/41 (sept.-oct. de 1931), pp. 200-206. - En su contrarréplica, incluida en el libro póstumo Sor Juana Inés de la Cruz, su misticismo y su vocación religiosa (México, 1968), Chávez se mantiene y se reafirma en su interpretación: las poesías amorosas de sor Juana, sin excluir "Esta tarde, mi bien..." ni "Silvio, yo te aborrezco...", "tienen tal intensidad de pasión que no pueden concebirse como cosa del pasado, compuesta a largos años de distancia. Afirmo, pues que [fueron escritas] antes de su entrada en el convento y rehechas [yo subrayo] años después".

${ }^{91}$ Igualmente, sólo alguien con mucha lectura de poetas españoles y con mucho colmillo pudo haber escrito los cinco sonetos burlescos mencionados supra, nota 87. El que Méndez Plancarte los juzgara obra de una adolescente es un claro disparate, explicable por la intensidad de su parti pris.

92 Cf. A. Alatorre, "La Carta de sor Juana al P. Núñez", NRFH, 35 (1987), pp. 595-599.

93 IRVING A. LeONARD, "The encontradas correspondencias of Sor Juana Inés de la Cruz”, HR, 23 (1955), 33-47 (o bien Baroque times in old Mexico, Ann Arbor, 1959, pp. 172-192): sor Juana "[was] not only torn between razón and pasión, but also between two methods of reason". Hablando como "amante", 
leer en la conclusión del soneto II - pero sólo allí- sería: 'Si mi vida va a ser un continuo angustiarme por no ser plenamente lo que quiero ser, más me vale ser una monja de tantas, aunque esto violente mi voluntad' ("violento empleo").

Pero creo que Leonard, por fijarse sólo en los tres sonetos, prescindiendo de los demás versos amorosos de sor Juana, no ve que la vehemencia dialéctica es al mismo tiempo vehemencia erótica. En un artículo publicado en 2001 trato de demostrar que las declaraciones de amor a Fabio son "metamorfosis" de las múltiples e inequívocas declaraciones de amor a la amabilísima condesa de Paredes, su libertadora y, durante siete floridos años, su interlocutora en la reja del convento ${ }^{94}$. Pero no toco allí el otro lado: las declaraciones de intenso aborrecimiento de los sonetos "Silvio, yo te aborrezco..." y "Cuando mi error y tu vileza veo...". ¿Quién es, en la realidad, ese Silvio a quien "Celia", ficción literaria, quiso en un tiempo y a quien ahora detesta? He aquí mi hipótesis: ese Silvio es el hombre que durante años se empeñó en ser el "director" de su espíritu. En la espléndida Carta alP. Núñezabundan las declaraciones del afecto que sor Juana le tuvo, pero estas declaraciones, aunque repetidas, quedan sofocadas bajo el peso de la firmísima declaración de independencia: el asedio del jesuita la tiene harta ("pues tomo la pluma..., es porque ya no puedo más"), y enérgicamente corta su relación con él. El tono de la Carta es mesurado, desde luego, pero en la metamorfosis poética, o sea en los dos sonetos de repudio a Silvio, puede sor Juana desahogarse y deplorar con acentos dramáticos los trece o catorce años en que se dejó manejar por el odioso padre Núñez. El destacado papel de los personajes Fabio y Silvio en la poesía de sor Juana corresponde al que la virreina y el jesuita tuvieron en su vid $a^{95}$.

¿qué es lo que busca sor Juana? Leonard responde: "Perhaps experimentalism, a secular freedom, and a newer age". Y en cuanto "ingrata", ¿qué es lo que deja? "Possibly scholasticism, ecclesiasticism, and medievalism". (Sin embargo, varias de las obras más serias de sor Juana, comenzando con la Crisis del sermón de Vieira y el auto del Divino Narciso, están abundante y gozosamente nutridas de "escolasticismo".)

94 Cf. A. Alatorre, "María Luisa y sor Juana”, Periódico de Poesía, 2001, núm. 2, pp. 8-37.

95 Cito, como curiosidad, la extravagante lectura de JuAn HurTado y Ángel González Palencia (Historia de la literatura española, 6a ed., Madrid, 1949, p. 540): en las redondillas "Hombres necios que acusáis..." se mostró sor Juana muy "severa" con los hombres; pero, "siendo consecuente, juzgó a las mujeres con análogo criterio", y aducen como prueba el soneto "Al que in- 
También en la comedia Amor es más laberinto resuenan ecos del Hanc amo ausoniano. A Teseo se le ofrecen dos partidos: Ariadna, que lo ama con verdadera locura (hasta el grado de acosarlo a ruegos, cosa tan impropia de una dama) y su hermana Fedra, que también lo ama, pero cuerdamente, con mesura (ella obedece todo el tiempo las leyes del "decoro") ${ }^{96}$.

En dos partes dividida tengo el alma en confusión: una, esclava a la pasión, y otra a la razón rendida,

dice famosamente sor Juana (décimas "Dime, vencedor rapaz...", núm. 99). Esas dos partes, que están "en confusión" dentro de su alma (o sea, revueltas la una con la otra) ${ }^{97}$, quedan artificialmente separadas e individualizadas o "personificadas” en Amor es más laberinto: Ariadna es la pasión y Fedra la razón. El final de la comedia es, por cierto, el de rigor: las dos "Infantas" se casan, Fedra con Teseo y Ariadna con el príncipe

grato me deja, busco amante..." (en el cual, según ellos, condena sor Juana la volubilidad del sexo femenino).

96 Explícita o implícita, la antítesis decoro/gusto aparece y reaparece multiformemente en la obra de sor Juana. Me detendré en una de esas reapariciones. Es obvio que la relación de la monja con Elvira de Toledo, condesa de Galve (cuyo marido comenzó a gobernar la Nueva España en 1688), no fue tan estrecha y tan cálida como la que había tenido con la condesa de Paredes, la virreina anterior. Y es igualmente obvio que le importaba vitalmente "cortejar" a esta señora, pues ¿cómo, sin tenerla de su lado, hubiera podido seguir haciendo lo que tanto le gustaba hacer? Pero Elvira no era la asidua visitante del locutorio de San Jerónimo que había sido María Luisa. Es éste el contexto de la felicitación de cumpleaños que le mandó, quizá en agosto de 1689 ("Si el día en que tú naciste...", núm. 42), donde le dice: "Entre el gusto y el decoro / quiere la razón que elija / lo que es adoración tuya [o sea, el adorarte a ti] / antes que la fruición mía. / / Yo me alegro de no verte, / porque fuera grosería / que te cueste una indecencia / el que yo logre una dicha". Sor Juana, pues, adora a la virreina, y nada la haría tan dichosa como poder verla; sí, pero se alegra de no verla: ¿cómo atreverse a desear que la divina Elvira se rebaje o condescienda a visitarla en la "reja" del convento? (Lo cual, bien visto, no es sino una manera de invitar a la virreina a un trato más asiduo.)

97 Como dice en las endechas "Agora que conmigo..." (núm. 78): "Salgan confusamente / suspiros que me abrasen, / lágrimas que me aneguen" (sin que sepa cuándo un suspiro es ya una lágrima, o una lágrima todavía un suspiro). 
Baco (amado antes de la llegada de Teseo a Creta, aborrecido en seguida, y ahora aceptado faute de mieux). Pero el lector de la comedia no podrá menos de observar que Ariadna, exaltada y pasional, es personaje mucho más complejo y mejor trabajado que Fedra, tan racional y "correcta".

La obra de sor Juana es el broche resplandeciente que cerró los siglos de oro. Después de ella nadie emuló a Calderón como ella en Los empeños de una casa y El divino Narciso, ni a Polo de Medina como ella en el Retrato de Lisarda, ni mucho menos a Góngora como ella en el Primero sueño, ni volvieron a hacerse sonetos a la rosa tan diáfanos y frescos como "Miró Celia una rosa que en el prado...". Tampoco volvieron a hacerse variaciones tan refinadas como las suyas sobre el dýseros, el viejo tema de la Antología griega y de Ausonio. Hay que llegar a la época llamada "neoclásica" para encontrar algún eco del multitudinario coro que hasta aquí hemos escuchado. Puede ser que se me haya escapado uno que otro texto de fines del siglo XVIII (y aun del xIx). Los que conozco son sólo dos: una nueva traducción del epigrama Hoc quod amare vocant por Juan Francisco López del Plano:
O mezcla o deshaz, por Dios, Amor, lo que amar se llama: a nadie abrase tu llama, o que abrase siempre a dos,

y el siguiente "cuarteto que una dama envió a otra, amiga suya, pidiéndola se le glosase":

Al que me amó aborrecí

[y] del que amé fui olvidada:

¡qué estrella tan rigurosa

es la que influye en mis ansias!

El primer texto es buen testimonio de la pequeña restauración de los estudios clásicos que se llevó a cabo a impulsos de la Ilustración. Gracias sobre todo a los jesuitas volvieron a hacerse, en España y sus colonias, cosas que desde tiempo atrás ya no se hacían, por ejemplo la traducción de poetas latinos (y aun griegos) y la lectura de poetas españoles bautizados ahora como "clásicos", o sea anteriores al ya superado Barroco. López del Plano hizo lo que más de un siglo antes había hecho Salazar y 
Torres (supra, p. 110), y lo hizo tan atinadamente como él; pero mientras que a Salazar, todavía barroco, le interesaba el conceptuoso tema en sí, lo que le interesa a López del Plano, ya ilustrado, es imitar la economía "clásica" de los epigramas latinos ${ }^{98}$. Su redondilla es un producto "erudito", de la misma especie que la concisa y fiel redondilla en que Bartolomé de Argensola había traducido el ausoniano Infelix Dido (cf. supra, nota 44).

El segundo texto es indicio de un fenómeno muy distinto, y aun opuesto. No es de índole "erudita", sino popular. Está en serie con las redondillas folklorizadas de otros tiempos, como el "Bras muere de amores de Ana" glosado en el siglo XVI por Gaspar de la Cintera y otros (supra, p. 107), o el "A quien quiero no me quiere" que le dieron a glosar en el xvir a Vicente Sánchez (supra, p. 116). Las modas literarias "formales" van cambiando al paso de los años, y así los poetas de la Ilustración desdeñan ya, por anticuado, el juego de ingenio de la "glosa", pero el juego sigue siendo estimado y practicado en el nivel "informal", entre los aficionados comunes y corrientes, o sea en el folklore lírico. Mi segundo texto - quizá cuarteta de romance, quizá copla de canción - fue enviado por una dama a otra dama aficionada a los versos, y ella lo glosó verso a verso ${ }^{99}$, tal como hacen todavía hoy, en México y otros países de lengua española, los poetas/músicos populares.

El folklore es, por esencia, conservador: una vez que las ideas, las costumbres, los ideales artísticos de las clases "altas" y "educadas" encuentran aprobación e imitación en "el pueblo", éste incorpora todo a su cultura, lo hace suyo. (He aquí un ejemplo clarísimo: los versos "ayer maravilla fui / y ahora ni sombra soy", de la canción "La Llorona", pertenecen a una letrilla de Góngora hecha en 1621, pero no llegó al folklore mexicano por el conducto artificial de la escritura, sino de boca en boca, desde los tiempos de Góngora hasta los nuestros.) Alguien definió el folklore como gesunkenes Kulturgut, adquisición

98 Juan Francisco López del Plano, Poesías selectas, Zaragoza, 1880, p. 379 (edición póstuma: el autor, nacido en 1758, había muerto en 1808). Puso en español el Arte poética de Horacio, y también otros tres epigramas de Ausonio.

99 M[aría] H[ICkey y Pellizoni], Poesías varias, Madrid, 1789, p. 286. En la p. 162 ha comenzado una serie de "Poesías varias de una dama de esta Corte. Dalas a luz doña M. H.”; pero son seguramente obra de la misma María Hickey y Pellizoni, que se hizo notar por su traducción de la Andromaque de Racine. 
cultural que lentamente ha ido hundiéndose y sedimentándose en ese mar que Unamuno llamó "la intrahistoria". Entre los millares de coplas del folklore mexicano que produjo la prolongada búsqueda de Margit Frenk y su equipo hay estas cuatro en que sigue resonando el dýseros ausoniano ${ }^{100}$ :

Si me arrimo, te retiras;

si me retiro, te enojas;

el caso es que para mí todititas son congojas.

Cuando te quiero te vas, cuando no te quiero vienes; dime por qué no te estás donde más cuenta tú tienes.

Cuando quise no quisiste, ahora que quieres no quiero: pasarás tu vida triste, cual yo la pasé primero.

¿De qué te sirve llorar y dar vueltas como loco, si tú te mueres por ella y ella se muere por otro?

Antonio Alatorre

El Colegio de México

100 Cancionero folklórico de México, ed. Margit Frenk et al., El Colegio de México, 1977, t. 2, núms. 3151b, 3152, 3363 y 3699. 